No. 11

FEBRERO DE 2017

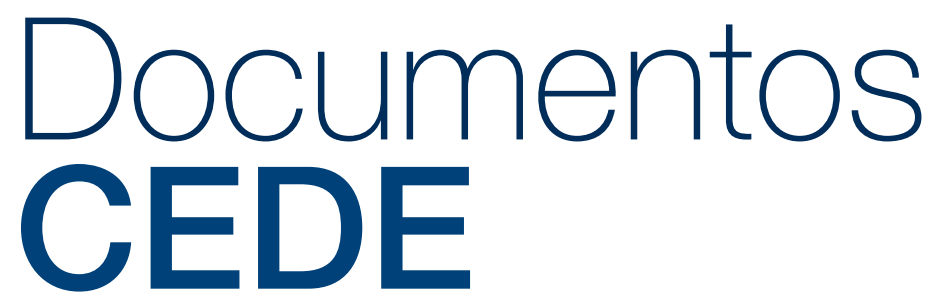

ISSN 1657-7191 Edición electrónica.

Does Better Teacher Selection Lead to Better Students? Evidence from a Large Scale Reform in Colombia

Zelda Brutti

Fabio Sánchez Torres 


\section{CEDE}

D1)

Facultad de Economía

Serie Documentos Cede, 2017-11

ISSN 1657-7191 Edición electrónica.

Febrero de 2017

(C) 2017, Universidad de los Andes, Facultad de Economía, CEDE. Calle 19A No. 1 - 37 Este, Bloque W.

Bogotá, D. C., Colombia Teléfonos: 3394949- 3394999, extensiones 2400 y 2049

infocede@uniandes.edu.co

http://economia.uniandes.edu.co

Impreso en Colombia - Printed in Colombia

La serie de Documentos de Trabajo CEDE se circula con propósitos de discusión y divulgación. Los artículos no han sido evaluados por pares ni sujetos a ningún tipo de evaluación formal por parte del equipo de trabajo del CEDE.

El contenido de la presente publicación se encuentra protegido por las normas internacionales y nacionales vigentes sobre propiedad intelectual, por tanto su utilización, reproducción, comunicación pública, transformación, distribución, alquiler, préstamo público e importación, total o parcial, en todo o en parte, en formato impreso, digital o en cualquier formato conocido o por conocer, se encuentran prohibidos, y sólo serán lícitos en la medida en que se cuente con la autorización previa y expresa por escrito del autor o titular. Las limitaciones y excepciones al Derecho de Autor, sólo serán aplicables en la medida en que se den dentro de los denominados Usos Honrados (Fair use), estén previa y expresamente establecidas, no causen un grave e injustificado perjuicio a los intereses legítimos del autor o titular, y no atenten contra la normal explotación de la obra.

Universidad de los Andes | Vigilada Mineducación

Reconocimiento como Universidad: Decreto 1297 del 30 de mayo de 1964. Reconocimiento personería jurídica: Resolución 28 del 23 de febrero de 1949 Minjusticia. 


\title{
Does Better Teacher Selection Lead to Better Students? Evidence from a Large Scale Reform in Colombia
}

\author{
Zelda Brutti* $\quad$ Fabio Sánchez Torres ${ }^{\dagger}$
}

\begin{abstract}
In 2002 the career of Colombian public school teachers was significantly reformed through the introduction of a selective entry competition and of further quality incentives. This paper estimates how the new quality-screened teachers impact students' high school performance. We exploit the fact that the novel regulation applied only to newly hired teachers, whereas those already in office in 2002 remained exempt, creating a mix of New-Regulation and Old-Regulation teachers in Colombian schools. Using data at the school-year-subject level, we eliminate any school-level confounders and associate the proportion of New-Regulation teachers to the variation in student test scores. We pin down a positive and significant, although not very large, effect of New Regulation teachers on student performance. New Regulation teachers have decreasing marginal returns, are more effective in larger schools and when surrounded by colleagues holding postgraduate degrees. We also document that the enforcement of the New Regulation has been somewhat unsatisfactory, since in the period 2008-2013 around 30\% of all New Regulation teachers are employed in temporary positions without having passed the compulsory entry exam. These teachers have lower and less robust impacts on student performance.
\end{abstract}

Key words: public education, teachers, student performance

JEL Codes: H52, H75, I20, I21, I28

*Universitat de Barcelona - zelda.brutti@ub.edu

†Universidad de Los Andes and CEDE - fasanche@uniandes.edu.co 


\title{
¿Una mejor selección de docentes se traduce en mejores estudiantes? Evidencia de una reforma a gran escala en Colombia
}

\author{
Zelda Brutti* $\quad$ Fabio Sánchez Torres ${ }^{\dagger}$
}

\begin{abstract}
En 2002 la carrera de los maestros de las escuelas públicas de Colombia fue reformada en forma significativa a través de la introducción de un examen de ingreso y de incentivos de calidad adicionales (Decreto 1278 de 2002). Este artículo estima el impacto de esa reforma sobre el desempeño de los estudiantes que terminan la secundaria y toman la prueba SABER 11. Explotamos el hecho de que la reforma sólo aplicó a las nuevas contrataciones de docentes, mientras que aquellos ya contratados en 2002 permanecieron exentos, creando una combinación en los colegios de Colombia de docentes de la nueva regulación y la antigua regulación. Utilizando datos a nivel de establecimiento-año-área de enseñanza, eliminamos cualquier factor que a nivel de establecimiento podría tener alguna influencia en los resultados y asociamos la proporción de docentes de la nueva regulación a la variación en el puntaje en pruebas estandarizadas de los estudiantes. Los resultados encontrados indican que una mayor proporción de maestros nuevos en un área particular (matemáticas, ciencias, lenguaje, etc.) está positivamente asociada con un mayor puntaje en la prueba SABER 11 en esa área particular, no obstante los efectos encontrados no son de gran magnitud. Adicionalmente, los docentes de la nueva regulación tienen rendimientos marginales decrecientes, son más efectivos en colegios grandes y cuando están rodeados de colegas con títulos de posgrado. También documentamos que el cumplimiento de la nueva regulación ha sido algo insatisfactoria, ya que en el periodo 2008-2013 cerca del $30 \%$ de los docentes de la nueva regulación están empleados en posiciones temporales sin haber pasado el examen obligatorio de ingreso. Estos docentes tienen impactos en desempeño menores y menos robustos.
\end{abstract}

Palabras clave: educación pública, docentes, desempeño escolar Códigos JEL: H52, H75, I20, I21, I28

\footnotetext{
*Universitat de Barcelona - zelda.brutti@ub.edu

$\dagger$ Universidad de Los Andes and CEDE - fasanche@uniandes.edu.co
} 


\section{Introduction and motivation}

The opening words of the 2016 OECD report on Colombian education read 'Colombia has made education a main priority to improve the economic and social prosperity of the country and pledged more resources to this sector than any other policy area' [OECD, 2016]. Indeed, over the past two decades the country has been transforming its education system on several aspects, and in this paper we are focusing on the quality assurance mechanisms that have been introduced to the teaching profession in 2002 in the effort of improving its standards.

Teacher hiring systems that feature competition on skills, such as national entry exams and performance rankings, may by now be common in the Western world but much less so in Latin America, Asia and Africa. Before the reform, in Colombia the career of public teacher was open to any candidate possessing the citizenship and given levels of education. The appointment of candidates into the open vacancies followed opaque evaluation processes, and once entered the career, salary and rank upgrades were based on seniority. This system lent itself to dynamics of corruption and clientelism [Duarte, 2001], beyond not creating any incentives for individuals to invest in their teaching skills and subject knowledge. Sadly, this type of structure is still common in many developing countries around the world ${ }^{1}$, making policy advice and careful reform evaluation in this context particularly urgent.

This paper analyzes the consequences of the introduction of a broad set of quality controls to the public teacher profession in Colombia. The quality controls can be summarized by (1) a public entry contest, that establishes the order in which candidates will choose vacancies 2) a probation period of 4 to 12 months, which confirms the appointment to the vacancies upon successful completion 3) continuous evaluation along the career, with yearly performance reports by the school headmaster, that can result in termination of the employment if unsatisfactory 4) salary upgrades being made conditional on skills evaluations, which are carried out through a written examination. We measure the impact of the reform on student performance at high school level, and find that bringing the share of New Regulation teachers from 0 to 1 in a given school year and subject increases the average performance of students by about $6 \%$ of a standard deviation.

We further explore heterogeneities in the effect across teacher and school characteristics. We find that the marginal effect of New Regulation teachers reaches more than double the average magnitude when the share of these teachers is still low $(<20 \%)$ in a given school year and subject: in other words, marginal returns are initially high and then decreasing. The effect of new teachers also depends positively on the number of colleagues in the year and subject, and on the share of postgraduate-holding colleagues. We are not able to pin down any significant relationship between

\footnotetext{
${ }^{1}$ We found many similarities between the pre-reform Colombian context and the current ones in many Latin American countries, such as Chile, Argentina, Brazil, Venezuela, Peru, Nicaragua, El Salvador and Panama'. For similar contexts in South Asia and the rest of the world, find discussions and details in Murillo et al. [2007], Hanushek [2009] and Hanushek and Woessmann [2012].
} 
the effect of New Regulation teachers on student performance and the average entry contest score of these teachers.

We also examine teacher retention patterns in the education system, and conclude that the professional incentive framework seems to be working partially, as having a postgraduate degree and scoring higher in the entry test is associated with longer permanence in the system, but the very top-scorers are observed dropping out faster than the median ones, suggesting a lower attractiveness of the profession for such teachers.

Finally, our empirical analysis suggests that loopholes in the new legislation may have allowed a conspicuous fraction of teachers to evade some of the quality assurance provisions, by teaching under the status of "temporaries" without having entered the career through the regular path. These teachers have a lower and less robust effect on student performance.

The next section briefly reviews the closest related works; Section 3 gives a thorough description of the most important aspects of the 2002 reform; Section 4 describes the data we use; Section 5 details the empirical strategy employed; Section 6 illustrates and discusses the results; Section 7 inquires into the channels of the effect; Section 8 explores time patterns of teachers; Section 9 does some robustness checks, followed by concluding remarks in Section 10.

\section{Closely related literature}

This paper contributes to the flourishing literature on teacher quality, which divides into several themes: assessing how much of the variation in student outcomes is explained by the teacher effect ${ }^{2}$; understanding which teacher characteristics make teachers better ${ }^{3}$; understanding which type of policies and interventions are effective in making teachers better or attracting and retaining better teachers ${ }^{4}$. The answer to our main exercise, quantifying the impact of New Regulation teachers on student performance, shall provide a reference point about the effectiveness of reforms such as the Colombian one ${ }^{5}$ in providing better teachers. The results of our secondary analyses on heterogeneity and retention patterns help towards understanding the channels of the reform effect, and suggests which types of teachers may find the profession appealing under a framework such as the Colombian one.

Closest to this paper both in scope and methodology we found work by Ome(2013, 2012), who also uses a fixed effects methodology to estimate the impact of the Colombian teacher career reform

\footnotetext{
${ }^{2}$ See for example Chetty et al. [2014], Rivkin et al. [2005], Rockoff [2005] and, for an excellent review, Hanushek and Rivkin [2012].

${ }^{3}$ For example Rockoff et al. [2011], Kane et al. [2008], Gordon et al. [2006]

${ }^{4}$ For example Hanushek et al. [2004], Figlio [2001]

${ }^{5}$ in a context similar to pre-reform Colombia, which is characteristic still today of many countries in Latin America, see footnote 1 .
} 
on primary and high school test scores. He uses three years of data on teacher records and student scores (2002, 2008 and 2009); he exploits within-school, across-year variation in the share of newregulation teachers to identify the effect of the new teachers. While pinning down positive effects at primary school level and on student dropout rates, he finds no effect of the New Regulation teachers on test scores at high school level. We think that the little amount of within-school variation in teacher composition across the three years might be the reason for the negative finding (low testing power).

\section{The 2002 reform of the teacher career}

\subsection{Pre-reform situation and reasons for the reform}

Before 2002, the teaching profession in Colombia was regulated by Decree 2277 of year 1979, and successive modifications. The appointment and transfers of teachers were considered administrative acts, and thus the responsibility of department governors and/or mayors ${ }^{6}$. There were requirements on the education levels for teachers at the different school grades. The scheme for career upgrades was based on combinations of years of service, education level and attendance of training workshops. Finally, teachers were guaranteed to remain in service until retirement age except in cases of ascertained severe misconduct ${ }^{7}$. Overall, the legal framework was characterized by very little transparency in procedures, excessive protection of employed teachers, and lack of incentives towards the improvement of skills and teaching performance. Clientelism and politicization of teacher appointments were substantial and well-known issues; far too often public schools were used as 'placement pools' for relatives and connections of influent personalities (see excellent descriptions and discussions in Duarte [2001] and Duarte [2003]).

\subsection{The new public contest procedure}

Teachers that have been entering the profession from January $1^{\text {st }} 2002$ onwards have to go through a public contest procedure in order to be assigned a vacancy. Contests are called separately for each education authority (department or certified municipality) and specify the vacancies available on their territories, and candidates must choose the one education authority they wish to apply to in that year. The contest is based on a score system and serves the purpose of establishing a rank among applicants, which determines the order in which successful candidates will be allowed to choose their preferred vacancies. The stages of the contest and their corresponding weights are summarized in Table 1; the subsequent subsections detail each stage further.

\footnotetext{
${ }^{6}$ See Art. 106 Ley $115 / 1994$

${ }^{7}$ Only in 1994 the law started to mention public contests as a desirable method of appointment of teachers, but these never took place until the 2002 reform.
} 
Table 1: Stages of the entry contest

\begin{tabular}{|c|c|c|c|c|c|c|}
\hline & \multirow[t]{2}{*}{ Purpose } & \multirow[t]{2}{*}{ Use of score } & \multirow[t]{2}{*}{$\begin{array}{l}\text { Minimum } \\
\text { threshold }\end{array}$} & \multicolumn{2}{|c|}{ Weight in contest } & \multirow[t]{2}{*}{ Responsibility } \\
\hline & & & & $\mathrm{T}^{*}$ & $\mathrm{H}^{*}$ & \\
\hline Exam & $\begin{array}{l}\text { Teaching aptitude, } \\
\text { subject knowledge }\end{array}$ & $\begin{array}{l}\text { Eliminatory } \\
\text { and ranking }\end{array}$ & $\begin{array}{l}60 \%(\mathrm{~T}) \\
70 \%(\mathrm{H})\end{array}$ & $55 \%$ & $45 \%$ & $\mathrm{ICFES}^{21}$ \\
\hline Exam & $\begin{array}{l}\text { Psychometric } \\
\text { test }\end{array}$ & Ranking & - & $10 \%$ & $10 \%$ & ICFES \\
\hline $\mathrm{CV}$ & $\begin{array}{l}\text { Credentials } \\
\text { evaluation }\end{array}$ & Ranking & - & $20 \%$ & $30 \%$ & $\begin{array}{l}\mathrm{CNSC}^{10} \text { or } \\
\text { delegate }\end{array}$ \\
\hline Interview & $\begin{array}{l}\text { Behavioral } \\
\text { evaluation }\end{array}$ & Ranking & - & $15 \%$ & $15 \%$ & $\begin{array}{l}\text { CNSC or } \\
\text { delegate }\end{array}$ \\
\hline
\end{tabular}

Note: $* \mathrm{~T}=$ teachers; $\mathrm{H}=$ headmasters

Source: MEN [2006]; MEN [2012]; GEARD [2013]

\section{The exam}

At the first stage of the contest, candidates sit an exam which is identical across the country and is administered and evaluated centrally by governmental agencies ${ }^{8}$; it is structured into three modules testing teaching aptitude, subject knowledge and psychometric values ${ }^{9}$. Candidates who do not score a minimum of $60 / 100$ points on each of the three modules must exit the contest. For surviving candidates, the exam stage will represent $65 \%$ of their global score (55\% for school directors).

\section{The evaluation of credentials}

Scores are assigned to academic degrees, additional training courses, academic productions and publications, past experience, past teaching evaluations (where present) and career awards, according to official tables set by $\mathrm{CNSC}^{10}$, the body in charge of this stage of the context. The credentials score represents $20 \%$ of the total (30\% for aspiring school directors).

${ }^{8}$ ICFES (Instituto Colombiano para la Evaluación de la Educación) and CNSC (Comisión Nacional del Servicio Civil). The exam registration fee is below 9 USD (2012-2013 contest). The exam questions are elaborated by the National University, the largest public university in Colombia.

${ }^{9}$ The 'aptitudes' module aims at assessing the candidate's ability to appropriately deal with language and numbers, and his knowledge of basic pedagogical concepts. The second module evaluates proficiency and skills of the candidate in his subject speciality. The psychometric test evaluates the candidate's hypothetical responses when facing pedagogical or institutional issues arising in the everyday teaching life.

${ }^{10}$ Comisión Nacional del Servicio Civil. It is an autonomous and independent body, located at the highest level in the structure of the Colombian State. It has legal identity and administrative, financial and managerial independence, and it is not part of any sector of the government authority. (Description translated from the institutional webpage of CNSC, http://www.cnsc.gov.co/index.php/institucional/direccionamiento-estrategico/quienes-somos-cnsc; fetched on 19 Jan 2015) 


\section{The interview}

The interview of candidates is also responsibility of CNSC, who may nominate local delegate bodies to decentralize the process. Typically universities and other certified higher education institutions are delegated and form ad hoc interview committees under the supervision of CNSC. The committee questions each candidate in person and the evaluation accounts for the remaining $15 \%$ of the global contest score.

\subsection{The probation period}

Once having completed the public contest and chosen one of the available vacancies according to his or her priority rank, the aspiring teacher starts a probation period that lasts up to the end of the ongoing academic year (minimum four months). At the end of probation, the candidate's performance is evaluated by the school headmaster, and conditional on a positive evaluation the new teacher takes permanent possession of the chair. Anecdotal evidence suggests that, in practice, very little further selection is happening at this stage, i.e. that virtually all teachers reaching the probation period are then appointed to the chair; in Table 7 we show statistical evidence supporting this claim.

\subsection{Permanent evaluation and incentives}

The New Regulation introduced permanent evaluation practices, aiming at ensuring a continued satisfactory performance by teachers, as well as providing them with incentives to improve over time.

The first form of permanent evaluation consists of yearly assessments compiled by school headmasters and reported to the local education authority, in which the headmaster comments on the teacher's performance following standardized criteria ${ }^{11}$. Two consecutive years of negative evaluations lead to discontinuation of the employment as a teacher. This change is important especially if compared to the over-protected status that teachers were enjoying under the old career regulation.

The second form of permanent evaluation and incentives brought in by the 2002 reform was making career upgrades conditional on passing public examinations that evaluate teachers' subject knowledge and teaching skills (Evaluación de Competencias). The new examination was added to the existing requirements of possessing the level of education required for the upper level, and of having spent 3 years at the current one (MEN [2013b]). The career structure and the corresponding pay scale of New Regulation teachers is different with respect to Old Regulation ones, and the two are illustrated in Table A.2, along with 2008 salary levels. Noticeable changes between the Old and the New Regulation are the introduction of a postsecondary specialization as the minimum education level for teachers ${ }^{12}$, and the reward of higher education degrees through higher salaries for teachers

\footnotetext{
${ }^{11}$ Evaluación anual de desempeño laboral. The current evaluation procedures are regulated in detail through Decree $3782 / 2007$ by the Ministry of Education.

${ }^{12}$ Bringing the minimum years of education from 11 (secondary education) to 13 or 14 (postsecondary specialization).
} 
holding them.

\section{Data}

\section{Data on teachers}

Data on teachers is available thanks to a the yearly information reporting procedure that is being enforced by the Ministry of Education across all public schools of the country ${ }^{13}$. Schools are required to give details on their pupils, staff and infrastructure, through the standardized formats set by the Ministry every year ${ }^{14}$. We have individual data on teachers at all public schools of the country for the years 2008 to 2013; each record includes the teacher's demographics, education level, school of placement, teaching subject, teaching level, type of contract, date first hired in the public education system, and salary level.

\section{Teacher test scores, and two types of New Regulation teachers}

Using their unique national ID document, we managed to match $81.15 \%$ of all New Regulation high school teachers ${ }^{15}$ to their entry exam scores. In the analysis we will use the most recent test score for each teacher, as the most up-to-date measure of his or her skills; Figure 1 graphs the density of these scores. Surprisingly, the mass of scores is below the minimum requirement of 60 points is very large. A worrying $34 \%$ of all new-regulation teachers who were holding a teaching position over the period 2008-2013 ${ }^{16}$ did not meet the minimum test score requirement on their most recent attempt ${ }^{17}$. Table 2 shows that a mere minority of these teachers have obtained a sufficient score at some point in the past ${ }^{18}$, leaving almost 13 thousand subjects in teaching positions without having ever passed the compulsory entry exam ${ }^{19}$. The law allows such individuals to fill teaching vacancies temporarily,

\footnotetext{
${ }^{13}$ Resolución 166 /2003 and following versions.

${ }^{14}$ The reasons behind the collection of this administrative data is for the Ministry to be able to monitor the status of the public education sector and to identify needs and priorities. School headmasters are in charge of ensuring the correct collection and reporting of the information, and of passing the data onto the local education authority ("education secretariat" of the department or certified municipality), which in turn reports to the Ministry of Education.

${ }^{15}$ That is 43,197 out of 53,234 New Regulation high school teachers. Overall we were able to match to their test scores 115,462 out of 145,724 New Regulation teachers $(79,23 \%)$. The unmatched part is largely due to a large number of missing IDs in the 2006 edition of the entry examination.

16 (and whom we were able to match with their scores)

${ }^{17}$ The figure could be reduced by matching the 2012 entry contest data, that was not available to us at the time of this project. If all teachers hired in 2012 and 2013 had regularly passed the exam, the percentage of those not having passed it would reduce to $28.36 \%$.

${ }^{18}$ And have been retaking the exam, for example, in order to move to a different education authority.

${ }^{19}$ And almost 37 thousand teachers overall, including the school levels other than secondary. These figures are a lower bound to the true ones, as we are missing the test scores of about $20 \%$ of our sample.
} 
Figure 1: Entry exam scores of teachers observed over 2008-2013

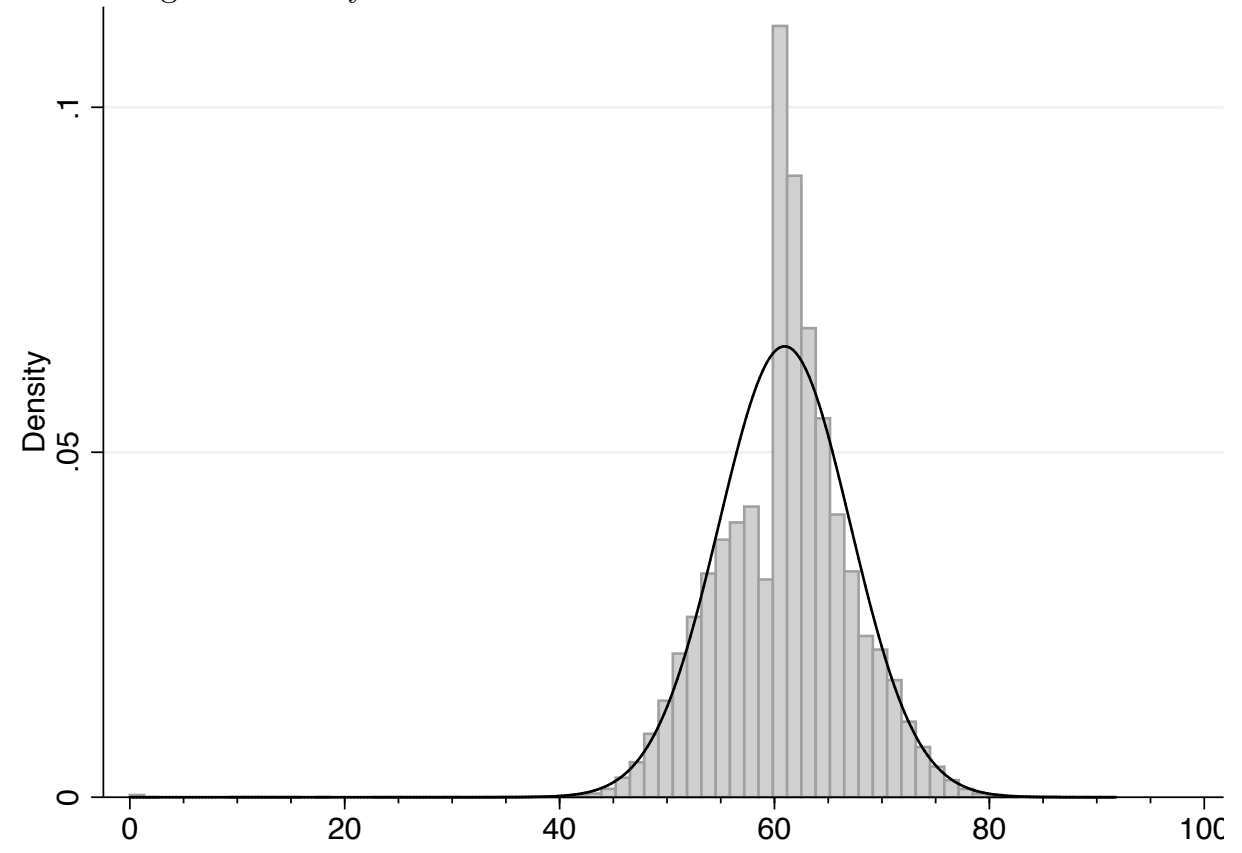

Density of entry test scores (most recent score of each teacher); bin width $=1.33$ points; normal curve is overlaid.

and only in the absence of legitimate candidates willing to fill the positions. In fact, Table 2 also reveals that $95 \%$ of teachers that have never passed the exam are holding temporary positions and $2 \%$ are registered as being on probation, while the remaining $3 \%$ has remarkably managed to land a permanent position.

Table 2: Teachers with most recent score below 60

\begin{tabular}{lccc}
\hline Type of position & Never above 60 & At least once above 60 & Total \\
\hline Permanent & 324 & 700 & 1024 \\
& $2.77 \%$ & $20.49 \%$ & $6.78 \%$ \\
Temporary & 11124 & 2456 & 13580 \\
& $95.11 \%$ & $71.9 \% 0$ & $89.86 \%$ \\
Probation & 248 & 260 & 508 \\
& $2.12 \%$ & $7.61 \%$ & $3.3 \% 6$ \\
\hline Total & 11,696 & 3,416 & 15,112 \\
& $100 \%$ & $100 \%$ & $100 \%$ \\
\hline \hline
\end{tabular}


These statistics split the group of New Regulation teachers into two potentially very different subgroups: New Regulation teachers who have at some point passed the entry exam and New Regulation teachers who have not, and we will refer to these two groups as "New Regulation Passed" and "New Regulation Not Passed" in the remainder of the paper.

\section{Data on student outcomes}

We will focus on high school test outcomes. The Colombian high school test is called Saber11 and is sat by students after 11 years of schooling, at completion of secondary school and before university ${ }^{20}$. Saber11 test data is collected by ICFES ${ }^{21}$ and it is the most complete among the standardized tests being conducted at different school grades; it is widely accepted as the reference examination to evaluate the quality of Colombian secondary education. Saber11 evaluates a range of seven school subjects, which are the same in all secondary schools ${ }^{22}$; test scores range from 0 to 100 in each subject and are standardized by subject at the national level, so that each student's score is informative about his/her position relative to the national average in that subject. Individual-level Saber11 test scores are made available by ICFES for the years 2000 to 2012, with information about the school and municipality to which each student belongs. We will use years 2008-2013 and associate them with the available teacher data.

\section{Matching students and teachers}

Unfortunately we do not have information on class groups, and thus we are unable to achieve a perfect match between teachers and the students they actually taught. The closest match we can obtain is between teachers teaching at secondary school level (years 6 to 11) in school $i$, year $t$ and subject $s$, and the Saber11 (year 11) student test scores in the same school $i$, year $t$ and subject $s$. Therefore our unit of observation is a school-year-subject cell, and we collapse and average the individual data to that level. Our main outcome variable is "Average test score", our regressor of interest is "Share of New Regulation teachers", which is given by the number of teachers hired under the New Regulation over the total number of teachers teaching the given subject at secondary level, in the given school, the given year.

\footnotetext{
${ }^{20}$ Schooling years 10 and 11 are not compulsory and are attended by around $41 \%$ of the eligible school population (2012 data: Sistema Nacional de Indicadores - Tasa de cobertura neta - Ministerio de Educación Nacional http://menweb.mineducacion.gov.co)

${ }^{21}$ Instituto Colombiano para la Evaluación de la Educación. The same agency also administers the national tests taken by students at different stages of their career. It is a governmental agency with social scope within the sector of public education; a national, decentralized public entity of special nature, with own legal identity, administrative independence and own assets; it is bound to the Ministry of Education. (Description translated from the institutional webpage of ICFES, http://www.icfes.gov.co/informacion-institucional/marco-legal; fetched on 19 Jan 2015)

${ }^{22}$ Mathematics; Spanish Language and Literature; Biology; Chemistry; Physics; Philosophy and English.
} 


\section{$5 \quad$ Empirical strategy}

We are interested in measuring the impact that the introduction of New Regulation teachers has had on student test scores. In our years of reference, 2008-2013, both New Regulation and Old Regulation teachers were teaching in Colombian secondary schools, and we will exploit this fact in order to identify the effect of the former. We also exploit the fact that within each school, students sit the exam on different subjects. We use heterogeneity in student performances and in the New Regulation teacher shares across subject, within the same school. Our main specification would be:

$$
y_{i t s}=\beta_{0}+\beta_{1} S N P_{i t s}+\beta_{2} S N N P_{i t s}+\boldsymbol{\beta}_{\boldsymbol{k}} \boldsymbol{X}_{\boldsymbol{k i t s}}+\alpha_{i t}+\alpha_{s}+e_{i t s}
$$

where the unit of observation is at the $\operatorname{school}(i)$-year $(t)$-subject $(s)$ level, $\alpha_{i t}$ is a school-year fixed effect, $\alpha_{s}$ is the subject fixed effect and $e_{i t s}$ is the residual. Our coefficient of interest is mainly $\beta_{1}$, on the share of New Regulation teachers that have passed the entry exam $(S N P)$, as this is the type of teachers the reform has been aiming at producing. Secondarily, we are also interested in coefficient $\beta_{2}$, on the share of New Regulation teachers that have not passed the exam $(S N N P)$, as it can provide an interesting comparison to $\beta_{1}$ and help us understanding the channels of the effect. This specification enables us to rule out any school-level factor or shocks which may induce selection of teachers into schools, or cause correlation between the share of New teachers and the student scores, such as school characteristics of both time-invariant and time-varying nature.

Similar regression models which do not feature school fixed effects are exposed to the bias induced by non-random selection of new-regulation teachers into schools. Those who feature school- but not school-year fixed effects (as in Ome [2012a]) are able to account for time-invariant sources of bias but still exposed to the spurious correlation between $y_{i t}$ and $S N P_{i t}$ or $S N N P_{i t}$ deriving from timevarying factors or shocks, such as changes in school management or shocks to school resources.

The next section presents our main results. Importantly, we find significant differences between the output of the more naïve school-fixed-effects model and that of the school-year-fixed-effects strategy we use.

\section{Main results}

Table 3 shows our main results, obtained estimating model (1) on the data previously described. We estimate a positive and significant effect of New Regulation - Passed teachers on student Saber11 scores, in a magnitude of about 0.20 points increase in the average score for that subject when the share of new-regulation teachers goes from 0 to 1 in that subject ( $6 \%$ of a subject standard deviation; $2 \%$ of a student standard deviation). Our preferred school-year-fixed effects specification in column (5) estimates an effect of New Regulation - Passed teachers by two thirds higher than the one we obtain through a regular school-fixed-effects model (column (3)). Estimations obtained without any 
within-school variation are very far off, reflecting strong sorting of teachers into schools (columns (1 and 2)).

Table 3: The effect of New Regulation teachers on student performance

\begin{tabular}{lllllc}
\hline & $(1)$ & $(2)$ & $(3)$ & $(4)$ & $(5)$ \\
\hline Share New Regulation Passed & $-0.56^{* * *}$ & $0.78^{* * *}$ & $0.12^{* * *}$ & $0.20^{* * *}$ & $0.20^{* * *}$ \\
& $(0.05)$ & $(0.07)$ & $(0.03)$ & $(0.04)$ & $(0.04)$ \\
Share New Regulation Not Passed & $-1.90^{* * * *}$ & $-0.33^{* * *}$ & -0.07 & $0.11^{*}$ & $0.11^{*}$ \\
& $(0.06)$ & $(0.08)$ & $(0.04)$ & $(0.05)$ & $(0.05)$ \\
Age & & $0.04^{* * *}$ & $0.03^{* * *}$ & $0.03^{* * *}$ & $0.03^{* * *}$ \\
& & $(0.01)$ & $(0.01)$ & $(0.01)$ & $(0.01)$ \\
Age^2 & $-0.00^{* *}$ & $-0.00^{* * *}$ & $-0.00^{* * *}$ & $-0.00^{* * *}$ \\
& & $(0.00)$ & $(0.00)$ & $(0.00)$ & $(0.00)$ \\
Experience & & $0.12^{* * *}$ & $0.02^{* * *}$ & $0.03^{* * *}$ & $0.03^{* * *}$ \\
& & $(0.01)$ & $(0.00)$ & $(0.00)$ & $(0.00)$ \\
Experience 2 & & $-0.00^{* * *}$ & $-0.00^{* * *}$ & $-0.00^{* * *}$ & $-0.00^{* * *}$ \\
Share postgrad degree & & $(0.00)$ & $(0.00)$ & $(0.00)$ & $(0.00)$ \\
& & $0.96^{* * *}$ & 0.01 & 0.02 & 0.02 \\
& & $(0.06)$ & $(0.02)$ & $(0.02)$ & $(0.02)$
\end{tabular}

\begin{tabular}{lccccc} 
Subject-specific trends & & & & & $\checkmark$ \\
\hline Subject FE & $\checkmark$ & $\checkmark$ & $\checkmark$ & $\checkmark$ & $\checkmark$ \\
School FE & & & $\checkmark$ & $\checkmark$ & $\checkmark$ \\
Year FE & $\checkmark$ & $\checkmark$ & $\checkmark$ & $\checkmark$ & $\checkmark$ \\
School-year FE & & & & $\checkmark$ & $\checkmark$ \\
Mean(y) & 43.33 & 43.33 & 43.33 & 43.33 & 43.33 \\
sd(y) & 3.29 & 3.29 & 3.29 & 3.29 & 3.29 \\
N.obs & 151,178 & 151,178 & 151,178 & 151,178 & 151,178 \\
N.groups & $\cdot$ & $\cdot$ & 5,969 & 29,609 & 29,609 \\
R-squared & 0.18 & 0.20 & 0.68 & 0.79 & 0.79 \\
\hline
\end{tabular}

Note: SE clustered by school in parentheses. Each observation is subject ' $\mathrm{s}$ ' in school ' $\mathrm{i}$ ' in year ' $y$ '. No fixed effects in columns (1) and (2), school fixed effects in column (3), school-year fixed effects in columns (4) and (5). ${ }^{*} \mathrm{p}<0.05,{ }^{* *} \mathrm{p}<0.01,{ }^{* * *} \mathrm{p}<0.001$

We estimate a positive and significant effect on student test scores also by New Regulation teachers who have not passed their entry exam, in a magnitude of about 0.14 points ( $4 \%$ of a subject- or $1.4 \%$ of a student standard deviation). The effect of this category of teachers will prove less robust to the inclusion of additional time and experience controls with respect to the effect of fully accredited teachers (see Table 9), but its magnitude is nevertheless non trivial. We devote section 7.4 to 
the discussion of this category, as we reflect upon the possible channels through which the reform operated. In the Appendix we also show estimation results obtained considering New Regulation teachers as a single group, without distinguishing between those who have passed the entry exam and those who have not (Table A.6).

\subsection{Falsification test}

Our main identification assumption is the absence of sorting of teachers across subjects, within each school and school year. This assumption would be threatened if we were facing dynamics such as subject-wise selective hiring, i.e. the targeted hiring of New Regulation teachers into a specific subject (within a school and school year). The legislative framework regulating Colombian public education is not suited to such dynamics, given the very limited freedom and decisional power that is left in the hands of single schools and principals - and hiring and firing of personnel is not among their rights ${ }^{23}$. Nevertheless, in order to lift any remaining doubts on these matters, we perform a falsification test that aims at detecting subject-level correlation between pre-reform student test scores and the postreform shares of New Regulation teachers in that subject. In other words, we estimate our main Model 1 using 2000 and 2001 test scores on the left-hand side, instead of post-reform scores. If New Regulation teachers were selectively entering subjects that 'needed' them because of bad performance, or that 'attracted' them because of good performance, a negative or positive correlation ought to emerge. Table 4 reports the coefficients on SNP and SNNP for each combination of pre-reform scores and post-reform teacher plant. As we can see, no correlation is detected in any of these combinations, bringing further support to our claim of absence of selection of teachers at the subject level.

\subsection{Nonlinear and interaction effects}

In this section we explore nonlinearities in the effect of New Regulation teachers on student subject performance. Firstly, we are interested in whether the marginal return to New Regulation teachers is constant across their share, or varying with it. We augment our main model (1) with the quadratic and cubic terms $S N P_{i t s}^{2}$ and $S N P_{i t s}^{3}$, allowing for a nonlinear response to increasing $S N P$, the share of New Regulation teachers who have passed their exam; Figure 2(a) shows the results graphically and Table A.8 numerically ${ }^{24}$. We find the marginal effect to be highest at low shares, starting as high as 0.75 points ( $22.8 \%$ of a school-year-subject standard deviation) and declining with the share, becoming statistically insignificant when SNP reaches values of around $40 \%$.

In Figures 2(b) and (d) and the corresponding Tables A.7 and A.10 we can see how the effectiveness of New Regulation teachers appears to increase with the number of colleagues in the year-subject,

\footnotetext{
${ }^{23}$ Except the evaluation post-probation period from 2002 onwards (see Section 7.2)

${ }^{24}$ In all panels of Figure 2 and the corresponding Tables, the sample has been limited to subject-years with 11 or less teachers ( 5 school-subject-year cells dropped).
} 
Table 4: Falsification: Share of New Regulation teachers on pre-reform student test scores

\begin{tabular}{lcccccc}
\hline Student test scores 2000 & 2008 & 2009 & 2010 & 2011 & 2012 & 2013 \\
\hline Share New Regulation Passed & 0.06 & 0.01 & 0.01 & -0.04 & -0.01 & -0.02 \\
& $(0.09)$ & $(0.08)$ & $(0.08)$ & $(0.08)$ & $(0.08)$ & $(0.07)$ \\
Share New Regulation Not Passed & 0.02 & 0.03 & 0.03 & -0.05 & 0.01 & 0.00 \\
& $(0.11)$ & $(0.10)$ & $(0.10)$ & $(0.10)$ & $(0.09)$ & $(0.08)$ \\
\hline N.obs & 11,715 & 12,395 & 12,395 & 13,366 & 14,188 & 15,204 \\
N.groups & 2,595 & 2,697 & 2,697 & 2,828 & 2,945 & 3,057 \\
\hline Student test scores 2001 & 2008 & 2009 & 2010 & 2011 & 2012 & 2013 \\
\hline Share New Regulation Passed & -0.05 & -0.01 & -0.03 & -0.08 & -0.09 & -0.01 \\
& $(0.08)$ & $(0.07)$ & $(0.07)$ & $(0.07)$ & $(0.07)$ & $(0.06)$ \\
Share New Regulation Not Passed & -0.01 & 0.03 & -0.02 & -0.03 & -0.08 & -0.02 \\
& $(0.10)$ & $(0.09)$ & $(0.10)$ & $(0.09)$ & $(0.09)$ & $(0.08)$ \\
\hline N.obs & 12,103 & 13,077 & 12,831 & 13,818 & 14,694 & 15,769 \\
N.groups & 2,696 & 2,783 & 2,798 & 2,932 & 3,054 & 3,171 \\
\hline
\end{tabular}

Note: Pre-reform student test scores regressed on each post-reform year's share of New Regulation teachers. SE clustered by school in parentheses. Each observation is subject ' $\mathrm{s}$ ' in school ' $\mathrm{i}$ ' in year 2000 or 2001. School and subject fixed effects, and all controls of Table 3 - model (5) are also included. ${ }^{*} \mathrm{p}<0.05,{ }^{* *} \mathrm{p}<0.01,{ }^{* * *} \mathrm{p}<0.001$

maybe suggesting positive network effects, and with the share of postgraduate-holding colleagues. Figure 2(c) and Table A.9 show an attempt at pinning down heterogeneous effects by quintiles of average entry tests scores of teachers: the Table reveals positive associations between student test scores and higher test performance of teachers, but the interactions with $S N P$ do not display interesting patterns. Finally, Figure 2(e) and Table A.11 show us that there are some differences in the effect of New Regulation teachers by subject taught, with the weakest effects on English foreign language and Philosophy, and the strongest on Mathematics.

\section{Channels of the effect}

\subsection{Selection on skills at entry}

The public contest at entry is certainly the most prominent among the novelties that were introduced by the 2002 reform of the teacher career. Its purpose is allowing the most suitable candidates to become school teachers, while keeping the less desirable ones out of the profession - and seeking to measure suitability with transparent and meritocratic criteria, as opposed to the politicized selections and placements that were common before the reform. The first stage of the contest, the written exam 
Figure 2: Marginal effects by different subject-year characteristics

The following panels plot the marginal effect of 'Share New Passed' on student test scores when the variable is interacted with other characteristics of the same subject-year: the share of New Passed itself and its square (own interactions), the number of total teachers, the average entry scores of

New Regulation teachers. Capped lines indicate $95 \%$ point-wise confidence intervals.

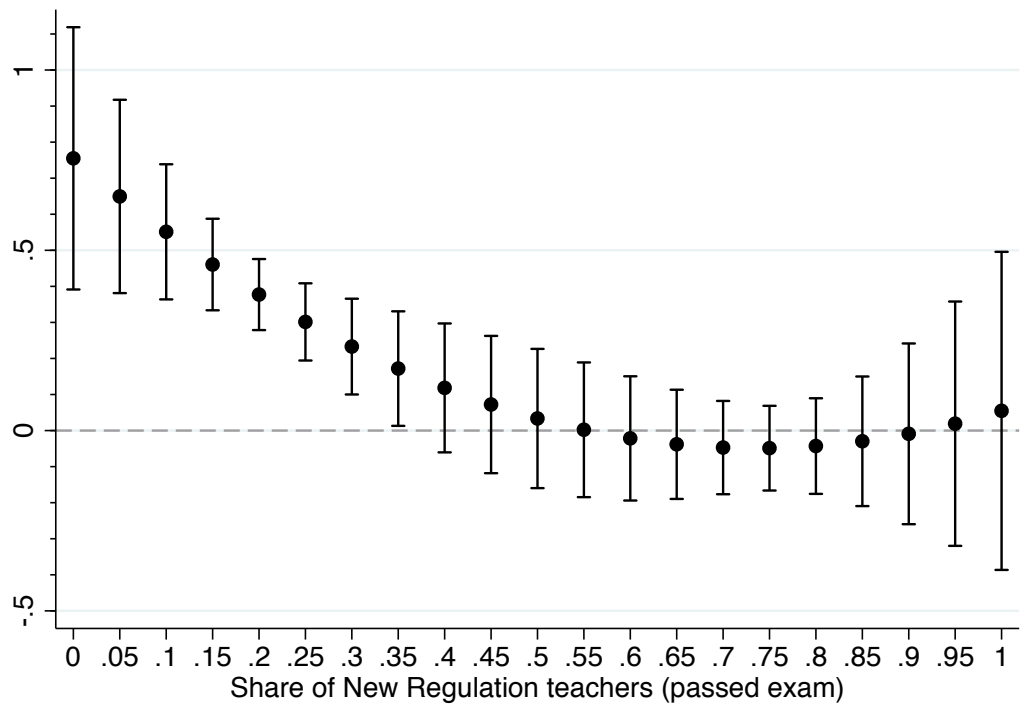

(a) Marginal effect at different levels of 'Share New Passed'

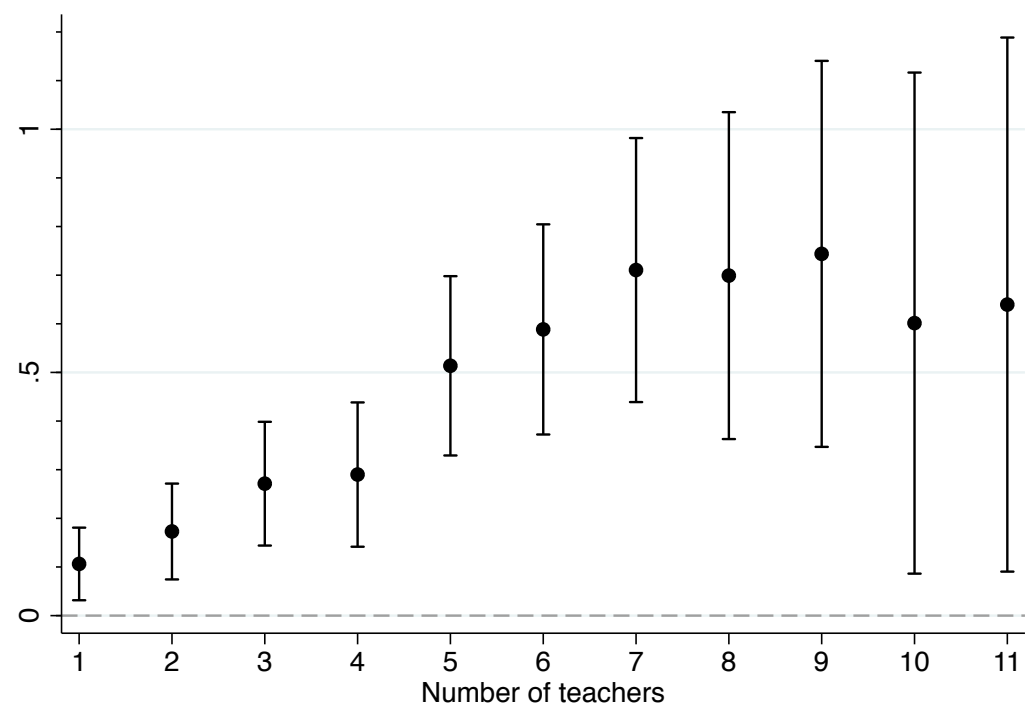

(b) Marginal effect at diffepent numbers of colleagues 


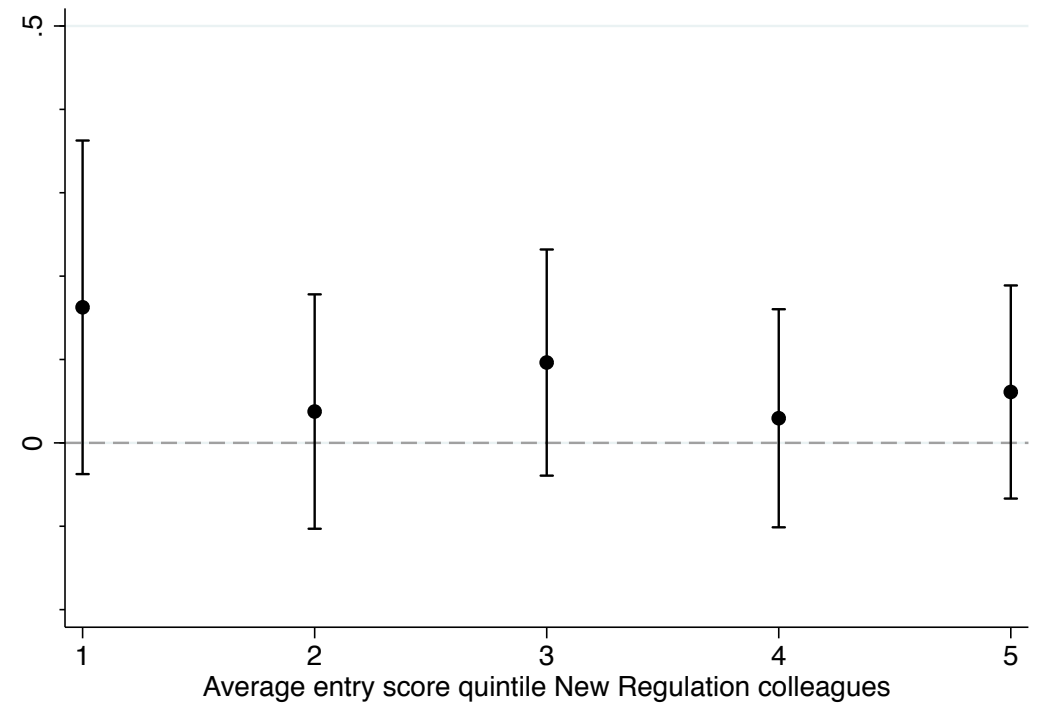

(c) Marginal effect at different quintiles of average entry scores

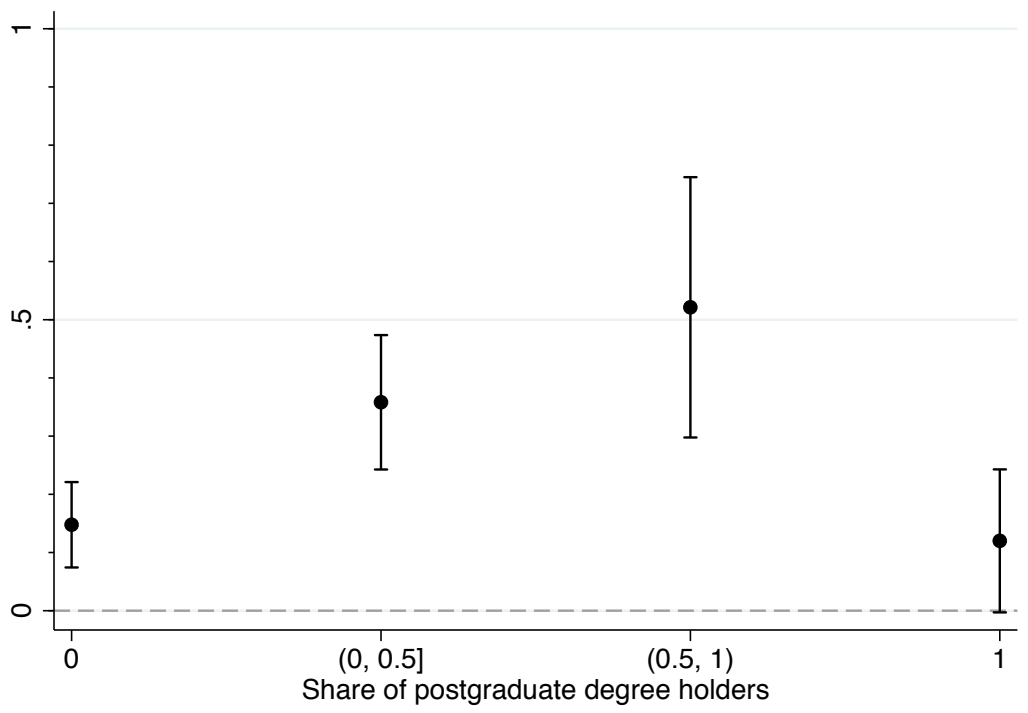

(d) Marginal effect at different shares of postgraduate degree holders 


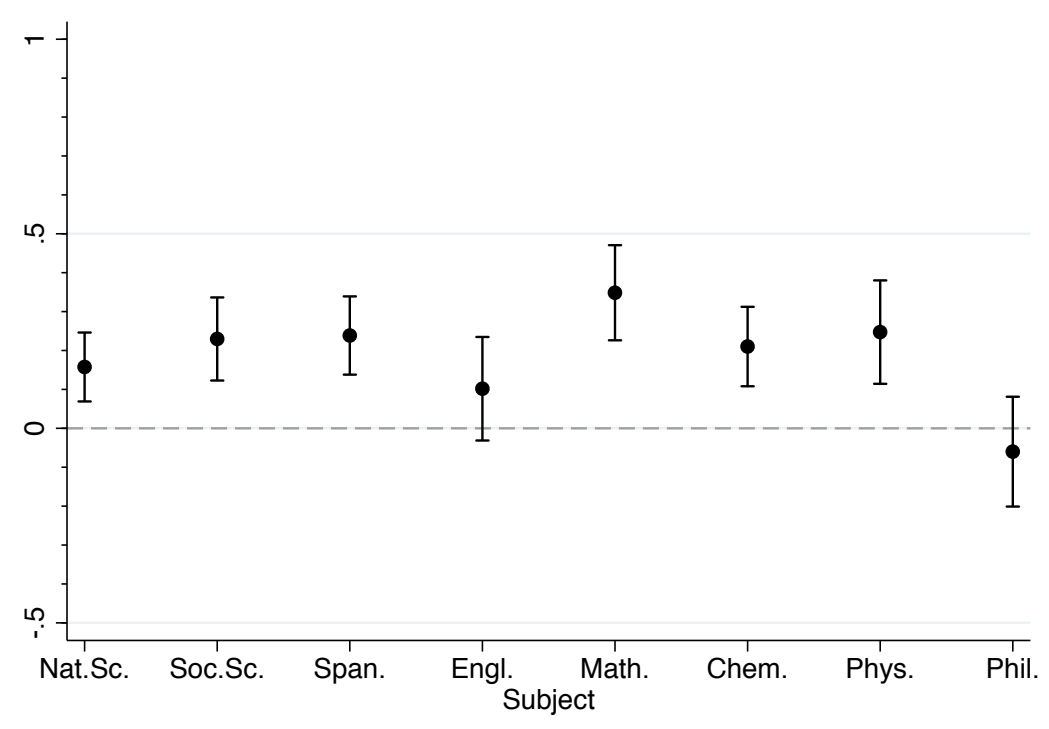

(e) Marginal effect at subjects

that is meant to evaluate knowledge and teaching aptitudes, accounts for a major share of the total score for a candidate (see the contest structure in Table 1). The minimum score threshold required in the exam seems to represent a tough hurdle for many candidates, and the first four contests saw exam-passing rates of only about $30 \%$ on average (Table A.1). In Table 5 we investigate the relationship between average teacher entry test scores and average student performance. The results show that such a relationship is significant even after controlling for teacher characteristics and for school, year and school-year fixed effects. That is, even within the same school and school year, different average teacher entry scores will determine different average student performance across subjects. Due to the fact that we observe only the skills (entry scores) of new regulation teachers, we are under-estimating the true relationship between teacher skills and student performance in Table 5. Table 6 shows the results of estimating lower and upper bounds for the true relationship, based on our bias derivation (section $\mathrm{F}$ in the Appendix), for different assumptions on the magnitude of $\operatorname{var}\left(\tilde{Q^{O}}\right) \cdot{ }^{25}$ In our most conservative estimates, raising average teachers skills from the 25 th to 75 th percentile in a given school, year and subject, raises average student performance by about $3.2 \%$ to

${ }^{25} \operatorname{var}\left(\tilde{Q^{O}}\right)$ is the variance of the residual one obtains hypothetically regressing $Q^{O}$, the measure of skills of traditional teachers, on all available controls and fixed effects (those included in our main result specification, Table 3, Column 5). $\operatorname{var}\left(\tilde{Q^{N}}\right)$ is the equivalent using $Q^{N}$, the measure of skills of new regulation teachers. 
$6.4 \%$ of a within-school-year standard deviation, and about $7 \%$ to $14 \%$ of a standard deviation when going from the 10th to the 90 th percentile ${ }^{26}$.

Table 5: Teacher's average entry exam score on student test scores

\begin{tabular}{|c|c|c|c|c|c|}
\hline & (1) & $(2)$ & $(3)$ & (4) & $(5)$ \\
\hline Teacher exam score & $\begin{array}{l}0.083^{* * *} \\
(0.003)\end{array}$ & $\begin{array}{l}0.013^{* * *} \\
(0.002)\end{array}$ & $\begin{array}{l}0.017^{* * *} \\
(0.002)\end{array}$ & $\begin{array}{l}0.008^{* * *} \\
(0.001)\end{array}$ & $\begin{array}{l}0.008^{* * *} \\
(0.001)\end{array}$ \\
\hline Share New & & & & & $\begin{array}{c}0.103^{*} \\
(0.048)\end{array}$ \\
\hline Experience & & & & $\begin{array}{l}0.021^{* * *} \\
(0.004)\end{array}$ & $\begin{array}{l}0.027^{* * *} \\
(0.005)\end{array}$ \\
\hline 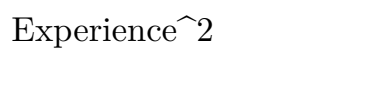 & & & & $\begin{array}{l}-0.001^{* * *} \\
(0.000)\end{array}$ & $\begin{array}{l}-0.001^{* * *} \\
(0.000)\end{array}$ \\
\hline Postgrad degree (share) & & & & $\begin{array}{c}0.012 \\
(0.034)\end{array}$ & $\begin{array}{c}0.013 \\
(0.034)\end{array}$ \\
\hline Subject-specific trends & & & & $\checkmark$ & $\checkmark$ \\
\hline Subject FE & & & & $\checkmark$ & $\checkmark$ \\
\hline School FE & & $\checkmark$ & $\checkmark$ & $\checkmark$ & $\checkmark$ \\
\hline Year FE & $\checkmark$ & $\checkmark$ & $\checkmark$ & $\checkmark$ & $\checkmark$ \\
\hline School-year FE & & & $\checkmark$ & $\checkmark$ & $\checkmark$ \\
\hline Mean $(y)$ & 43.39 & 43.39 & 43.39 & 43.39 & 43.39 \\
\hline $\mathrm{sd}(\mathrm{y})$ & 3.26 & 3.26 & 3.26 & 3.26 & 3.26 \\
\hline N.obs & 106,552 & 106,552 & 106,552 & 106,552 & 106,552 \\
\hline N.groups & & 5,887 & 27,919 & 27,919 & 27,919 \\
\hline R-squared & 0.03 & 0.52 & 0.66 & 0.81 & 0.81 \\
\hline
\end{tabular}

Note: SE clustered by school in parentheses. Each observation is subject ' $\mathrm{s}$ ' in school ' $\mathrm{i}$ ' in year 'y'. ${ }^{*} \mathrm{p}<0.05,{ }^{* *} \mathrm{p}<0.01,{ }^{* * *} \mathrm{p}<0.001$

\subsection{Selection on the probation period}

The probation period that teachers begin after having successfully passed the entry contest and selected their preferred vacancy, is a further selection mechanism that the 2002 reform put in place. School headmasters observe and evaluate the new teachers during their first months of employment, and have the power to end their employment if deemed unfit for the job. Anecdotal evidence suggests that, in practice, the firing of teachers after their probation period is a rare event, due to the fact

\footnotetext{
${ }^{26}$ These magnitudes are about half of what the main literature finds for teacher fixed effects in the US (see the summary in by Hanushek and Rivkin [2012], Table 1)
} 
Table 6: Estimation of the true relationship between teacher quality and student performance

1) Lower and upper bound of the true $\beta$, based on the estimated $\hat{\beta}$

\begin{tabular}{c|c|c|c} 
& & $(\mathrm{A})$ & $(\mathrm{B})$ \\
& $\operatorname{var}\left(\tilde{Q^{O}}\right) \simeq \operatorname{var}\left(\tilde{Q^{N}}\right)$ & $\operatorname{var}\left(\tilde{Q^{O}}\right) \approx 2 \operatorname{var}\left(\tilde{Q^{N}}\right)$ & $\operatorname{var}\left(\tilde{Q^{O}}\right) \approx \frac{1}{2} \operatorname{var}\left(\tilde{Q^{N}}\right)$ \\
& $\beta \approx 1.23 \hat{\beta} \approx 0.010$ & $\beta \approx 1.12 \hat{\beta} \approx 0.009$ & $\beta \approx 1.33 \hat{\beta} \approx 0.011$ \\
Lower bound & $\beta \approx 2.44 \hat{\beta} \approx 0.020$ & $\beta \approx 3.03 \hat{\beta} \approx 0.024$ & $\beta \approx 2.13 \hat{\beta} \approx 0.017$
\end{tabular}

2) Estimated effect of increasing average teacher quality in a given school, year and subject

\begin{tabular}{ll|l|l}
25 th $\rightarrow 75$ th pctile & $+3.2 \%$ to $6.4 \%$ s.d. & $+2.9 \%$ to $7.7 \%$ s.d. & $+3.5 \%$ to $5.5 \%$ s.d. \\
10 th $\rightarrow$ 90th pctile & $+7.0 \%$ to $13.9 \%$ s.d. & $+6.3 \%$ to $16.7 \%$ s.d. & $+7.7 \%$ to $11.9 \%$ s.d.
\end{tabular}

that headmasters do not wish to incur in the hassle of potential appeals and legal disputes that fired teachers would recur to. We test this claim using our six years of school censuses (2008 to 2013) and constructing an individual-level panel that records the type of position that each New Regulation teacher holds each year: permanent, temporary ${ }^{27}$ and in probation. We then estimate a model $Y_{i t}=\beta_{0}+\beta_{1}$ Temp $_{i t}+\beta_{2}$ Prob $_{i t}+\epsilon_{i t}$, where $Y_{i t}=1$ if the teacher is still in the panel in period $t+1$ and 0 otherwise ${ }^{28}$; Temp and Prob are mutually exclusive dummies indicating the type of position held in year $t$ (omitted category is Perm, permanent position). We then also add the Age $_{i t}$ controls to the baseline (columns (2) and (4)). In Columns (3) and (4) we adopt a random effects specification, adding individual teacher effects $\alpha_{i}$ to our model. All columns report the odds ratios from our maximum-likelihood logit estimates. The results of Table 7 may tell a different story with respect to the previous anecdotal evidence: teachers on probation are only about $80 \%$ as likely as permanent position teachers to still be recorded system the year after. Nevertheless, we do not know the reasons behind the sample attrition and we are thus unable to distinguish between teachers who have voluntarily quit their job and those sacked. It may be that the first year of employment regularly sees higher dropout rates with respect to the following ones, due to initial adjustment or unmet expectations of new entrants. In conclusion, even though we do find considerably higher teacher dropout rates associated with their probation period, we are unable to conclusively say whether this provision of the reform is implementing selection on new teachers.

\footnotetext{
${ }^{27}$ There are two types of temporary statuses: 'Temporary in permanent vacancy', meaning that the vacancy is waiting to be filled with a new permanent occupant, and 'Temporary in temporary vacancy' means that the vacancy has a permanent occupant who is only temporarily away. We have grouped the two categories into a single one for our analysis.

${ }^{28}$ We do not use $Y_{i, 2013}$, which is equal to 0 for all subjects, since the panel ends in 2013.
} 
Table 7: Panel retention by type of position held (New Regulation teachers)

\begin{tabular}{lccccc}
\hline & \multicolumn{2}{c}{ Logit } & & \multicolumn{2}{c}{ RE Logit } \\
\cline { 2 - 3 } \cline { 5 - 6 } & $(1)$ & $(2)$ & & $(3)$ & $(4)$ \\
\hline \multirow{2}{*}{ Temporary position } & $0.25^{* * *}$ & $0.25^{* * *}$ & & $0.19^{* * *}$ & $0.19^{* * *}$ \\
Probation period & $(0.00)$ & $(0.00)$ & & $(0.00)$ & $(0.00)$ \\
& $0.77^{* * *}$ & $0.77^{* * *}$ & & $0.78^{* * *}$ & $0.78^{* * *}$ \\
Age bins & $(0.03)$ & $(0.03)$ & & $(0.03)$ & $(0.03)$ \\
N.obs & No & Yes & & No & Yes \\
N.groups & 138,869 & 138,865 & & 138,869 & 138,865 \\
\hline
\end{tabular}

Note: Odds ratios displayed. Outcome variable: $\mathrm{Y}=1$ if the teacher is still in the panel the following year, 0 otherwise. Year 2013 excluded. Columns (1) and (2): SE clustered by individual in parentheses. Columns (3) and (4): Observed Information Matrix SE in parentheses. ${ }^{*} \mathrm{p}<0.05$, ** $\mathrm{p}<0.01,{ }^{* * *} \mathrm{p}<0.001$

\subsection{Turnover and discontinuation of employment}

We can distinguish discontinuation of employment for Colombian public teachers into forced and voluntary. It is forced when the teacher is dismissed from his or her employment against his or her will, and it is voluntary when the teacher leaves the profession by own decision.

In section 3 we discussed how new-regulation teachers, contrary to their old-regulation colleagues, face the threat of seeing their employment discontinued for reasons other than severe misconduct. As an incentive to effort and good teaching, discontinuation of employment may happen due to two consecutive years of unsatisfactory scores on the performance evaluations which are carried out by school headmasters.

Unfortunately we do not have access to data on these yearly performance evaluations, but we can start exploring the question of whether new regulation teachers are experiencing significant screening even once their careers are underway by examining in-career dropout patterns. Table 8 shows maximum likelihood logit estimations of the model $Y_{i}=\beta_{0}+\beta_{1} N e w R e g_{i}+\epsilon_{i}$, where $Y_{i t}=1$ if the teacher is still in the panel in period $t+1$ and 0 otherwise; and $N e w R e g_{i}$ is a dummy taking value 1 for new-regulation teachers and 0 for old-regulation ones; again we also add the $A g e_{i}$ control to the baseline. In Columns (3)-(4) we adopt a random effects specification, adding individual teacher effects $\alpha_{i}$ to our model ${ }^{29}$. Conditional on having reached the permanent-position stage, New Regulation teachers actually display higher panel retention rates than their traditional-regulation colleagues,

\footnotetext{
${ }^{29}$ In this case fixed effects estimation is not feasible, as the new-regulation or old-regulation status is time-invariant.
} 
even controlling for age ${ }^{30}$. In conclusion, we are unable to find any evidence for high rates of forced employment termination occurring among teacher subject to the reformed rules, and we are inclined towards ruling out this channel as an important selection mechanism.

Table 8: Panel retention per type of teacher regulation (permanent-position teachers)

\begin{tabular}{|c|c|c|c|c|c|c|}
\hline & \multicolumn{3}{|c|}{ Logit } & \multicolumn{3}{|c|}{ RE Logit } \\
\hline & (1) & (2) & (3) & (4) & (5) & (6) \\
\hline New Regulation & $\begin{array}{l}1.978^{* * *} \\
(0.030)\end{array}$ & $\begin{array}{l}1.516^{* * *} \\
(0.028)\end{array}$ & $\begin{array}{l}1.229^{* * *} \\
(0.022)\end{array}$ & $\begin{array}{l}2.409^{* * *} \\
(0.044)\end{array}$ & $\begin{array}{l}1.759^{* * *} \\
(0.038)\end{array}$ & $\begin{array}{l}1.313^{* * *} \\
(0.026)\end{array}$ \\
\hline Age & & $\begin{array}{l}0.979 * * * \\
(0.001)\end{array}$ & $\begin{array}{l}0.972^{* * *} \\
(0.001)\end{array}$ & & $\begin{array}{l}0.975^{* * *} \\
(0.001)\end{array}$ & $\begin{array}{l}0.971^{* * *} \\
(0.001)\end{array}$ \\
\hline Year dummies & No & No & Yes & No & No & Yes \\
\hline $\begin{array}{l}\text { N.obs } \\
\text { N.groups }\end{array}$ & 309,383 & 309,383 & 309,383 & $\begin{array}{r}309,383 \\
94,285\end{array}$ & $\begin{array}{r}309,383 \\
94,285\end{array}$ & $\begin{array}{r}309,383 \\
94,285\end{array}$ \\
\hline
\end{tabular}

Note: Outcome variable: $\mathrm{Y}=1$ if the teacher is still in the panel the following year, 0 otherwise. Columns (1)-(3): SE clustered by individual in parentheses. Columns (4)-(6): Observed Information Matrix SE in parentheses. ${ }^{*} \mathrm{p}<0.05,{ }^{* *} \mathrm{p}<0.01,{ }^{* * *} \mathrm{p}<0.001$

\subsection{New Regulation teachers that have not passed the entry exam}

Let us now turn to discuss the results we obtained on the second category of New Regulation teachers, those who have not passed their entry exam (the SNNP variable, for "Share New Not Passed"). In the main results of Table 3, column (5), we see that the positive impact of these teachers on student outcomes is estimated at around $70 \%$ of the impact of teachers who did pass the entry exam. Teachers who have not passed the exam can be employed temporarily, in absence of fully accredited candidates. Nevertheless, they have not officially entered the teaching career and are thus not eligible for any career upgrades: their salary is locked to the first step (step A) of the level to which they would belong if they passed the exam ${ }^{31}$ (see Table A.2 for an idea about numbers). These teachers, the vast majority of which occupies temporary positions (see Table 2), is also at constant risk of being replaced by candidates who do pass the exam, as only the latter are entitled to take permanent possession of vacancies. The positive impact that this category of teachers has on student test scores, thus still improving on Old Regulation teachers, can probably be attributed to the effort that they are exerting towards obtaining their full accreditation and overcoming their precarious status in the

\footnotetext{
${ }^{30}$ Various other flexible forms of controlling for age have been tested without significant changes in the results, and have thus been omitted in the output.

${ }^{31}$ Decree $624 / 2008$.
} 
system. In this regard, it is important to keep in mind that even though they have obtained a score below 60 , these teachers have attempted the entry exam at least once, and almost $60 \%$ of them have attempted it multiple times ${ }^{32}$, and are thus likely to have gone through preparation and quality assurance procedures similarly to their successful colleagues. Moreover, they do possess the preliminary requirements needed to access the entry contest, including the higher education level requirements introduced by the reform. These considerations may explain quite well our finding of a still positive but about $30 \%$ lower impact on student test scores that these non-accredited teachers are bringing about, and are consistent with our previous deductions about a positive selection being implemented through the entry exam and possibly through the probation period.

\section{Exploring time patterns}

We further pursue the understanding of how the two regulations translate into career differences by analyzing survival patterns in Old and New public teachers. A public teacher becomes "at risk of failing" the year in which he/she enters the teacher profession, and "fails" the year in which he/she exits it for whichever reason. The survival analysis performed in this section is based on the individual-level information recorded over the direct observation period 2008-2013 $3^{33}$, and on the retrospective information about each teacher's first hiring year ${ }^{34}$. The survival time of teachers hired before the start of our observation window in 2008 is treated as conditional on having survived already up to that year ${ }^{35}$. In the whole analysis, the sample has been limited to exclude teachers who voluntarily switched from the Old to the New Regulation (by taking the exam) and the other cases in which the regulation recorded is inconsistent with the year of hiring (3,902 teachers), as well as the teachers who are recorded as not exercising in an educational structure (1,899 teachers). The remaining sample consists of 118,117 teachers teaching one of the Saber 11 test subjects at secondary level ${ }^{36}$, among which 64,883 belong to the Old regulation and 53,234 to the New one $(43,197$ with matched test scores).

As a first exercise, we estimate the survival functions corresponding to old regulation and new regulation teachers non-parametrically, and plot them in Figure 3. Notice that since our observation

\footnotetext{
${ }^{32} 7,392$ out of 12,895 teachers have attempted the exam 2, 3 or 4 times between 2002 and 2009

${ }^{33}$ Or a subset of those years, for teachers hired during that time span.

${ }^{34}$ The first hiring date is the date in which the teacher was hired for the first time as a public school teacher.

35 i.e. we are in the presence of "left censoring". See the excellent discussion in Wooldridge [2010], ch. 22.3.3.

${ }^{36}$ In the Appendix, we also show the results of the analysis on the 360,644 teachers teaching at any preschool, primary and secondary level in the country. The patterns identified in the full sample follow closely those found in the limited one.
} 
Figure 3: Kaplan-Meier survivor functions by regulation - Secondary teachers

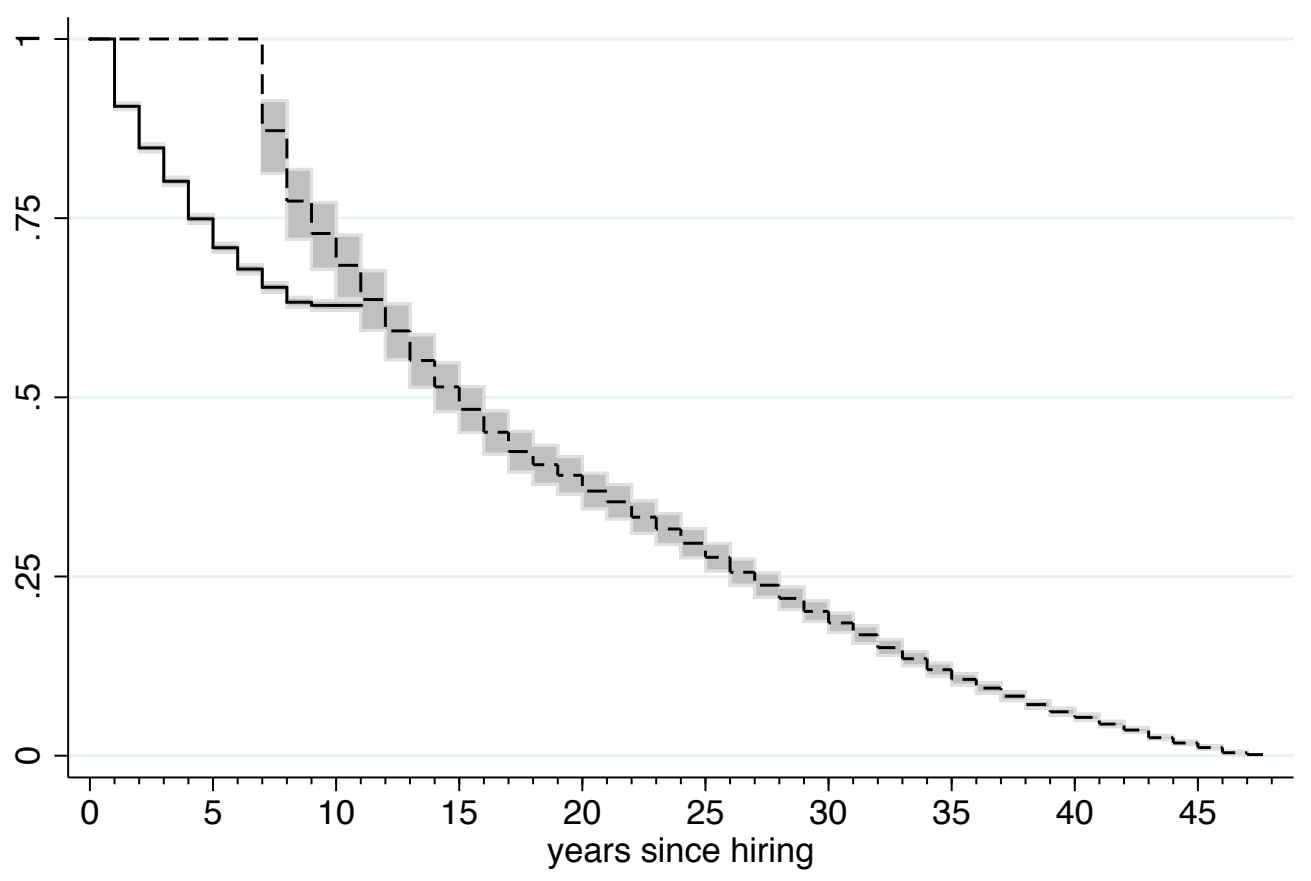

Kaplan-Meier survivor functions for teachers belonging to the new regulation (solid line) and the old regulation (dashed line), and $95 \%$ confidence intervals. Secondary teachers only.

window spans the years 2008-2013 and the new teacher regulation was implemented in 2002, any oldregulation teacher we observe has already spent at least 6 years in the public education system (which explains the 'shifted' starting point of the dashed curve in Figure 3). On the other hand, the most senior new-regulation teachers we observe have spent not more than 11 years in the system (which explains the 'early' end of the solid curve in the figure). The two survival functions are therefore shifted with respect to each other, with few years of time overlap. This situation makes it difficult to compare the two survival patterns directly, since the most interesting comparisons between groups are made looking at the same time from origin, or years since hiring in this case ${ }^{37}$.

We further explore how observable characteristics of teachers are associated with differences in survival patterns. We show graphical results in Figure 4 and 5 for teachers belonging to the old and the new regulation respectively. Overall we do not find striking differences in the way teacher

\footnotetext{
${ }^{37}$ For example, looking at Figure A.2 one might conclude that new-regulation teachers experience a quite steep dropout pattern during their early years of career (say the first five), but one cannot tell whether the same applies to old-regulation teachers, as we do not observe them in such early years
} 
characteristics affect survival patterns under the two regulations. Holding a postgraduate degree is associated with significantly higher survival rates with respect to not holding one; being female and being located in a rural area associate with somewhat lower permanence in the system, especially under the new regulation; as it is natural, survival decreases as the age at which the teachers first entered the system. In the following subsection we will give special consideration to the patterns on teacher entry scores, depicted panel (e) of Figure A.4.

\subsection{Entry exam scores}

A very interesting dimension to look at for the case of New Regulation teachers is their entry test score. We would expect teachers that score higher on the entry test to survive longer in the system, under the assumptions that 1) the new regulation is effective in rewarding skills and keeping highly skilled teachers in the system, and effective in eliminating unsatisfactory teachers and 2) the entry exam is a good measure of the desirable skills that the reform is aiming at. To the support of aspect 2), we shall recall the positive correlation we found between teacher entry scores and student performance in our heterogeneity analysis (see Table A.9). Regarding aspect 1), previous work by Ome [2012b, 2013] has evidenced how the 2002 reform has made the teaching profession more attractive to high skilled individuals, due to the change in the salary structure and the potentially quicker ascent to top salary levels ${ }^{38}$.

We have divided teachers into quartiles ${ }^{39}$ according to their performance in the most recent entry exam they took, and we plot the survival rates of the four groups in Panel (e) of Figure A.4. We notice how the first (lowest-scoring) quartile exits from the teacher profession at a dramatically faster rate with respect to the other three. All teachers in the first quartile and part of those in the second quartile have scored below the 60 points required to pass the exam and proceed to the following stages of the entry context, on their most recent attempt. Back in Table 2 and in Section 7.4 described how a majority of these individuals has actually never passed the entry exam, expressing our concern about the significant share of teaching positions they occupy. The survival patterns we describe are consistent with those facts and provide us with some food for thought: on one hand, we find confirmation of the rather unstable nature of the employment histories of non-accredited New Regulation teachers, with respect to their better performing colleagues. On the other hand though, we notice that the instability may be lower than it ought to be, given that the survival chance of these individuals in the public school system is around $50 \%$ even after 10 years of employment.

A final interesting aspect to notice is that the relationship between exam score quartiles and

\footnotetext{
${ }^{38}$ If we consider education level as a proxy for skills, our own data collection summarized in Table A.2 confirms this view for both individuals holding postsecondary degrees and those holding university (undergraduate or postgraduate) degrees: compared to the Old Regulation, the former are now enabled to reach salary levels double as high, and the latter face a potentially much quicker ascent to the top salaries.

${ }^{39}$ The score ranges defining quartiles are $[0,58.35],(58.35,61.4],(61.4,64.55]$ and $(64.55,100]$.
} 
Figure 4: Kaplan Meier survival functions by teacher characteristics (Old regulation) - Secondary teachers

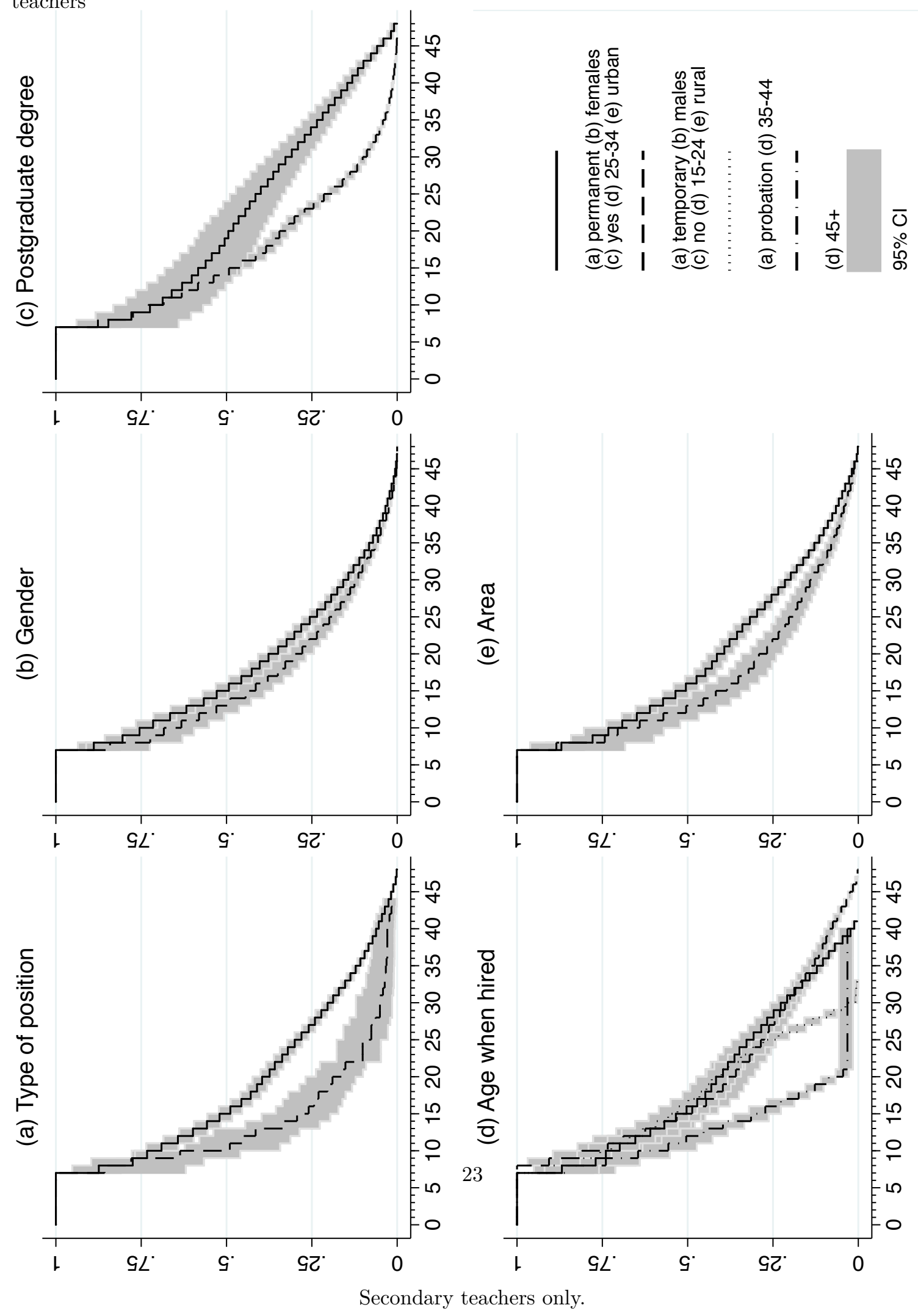


Figure 5: Kaplan Meier survival functions by teacher characteristics (New regulation) - Secondary teachers
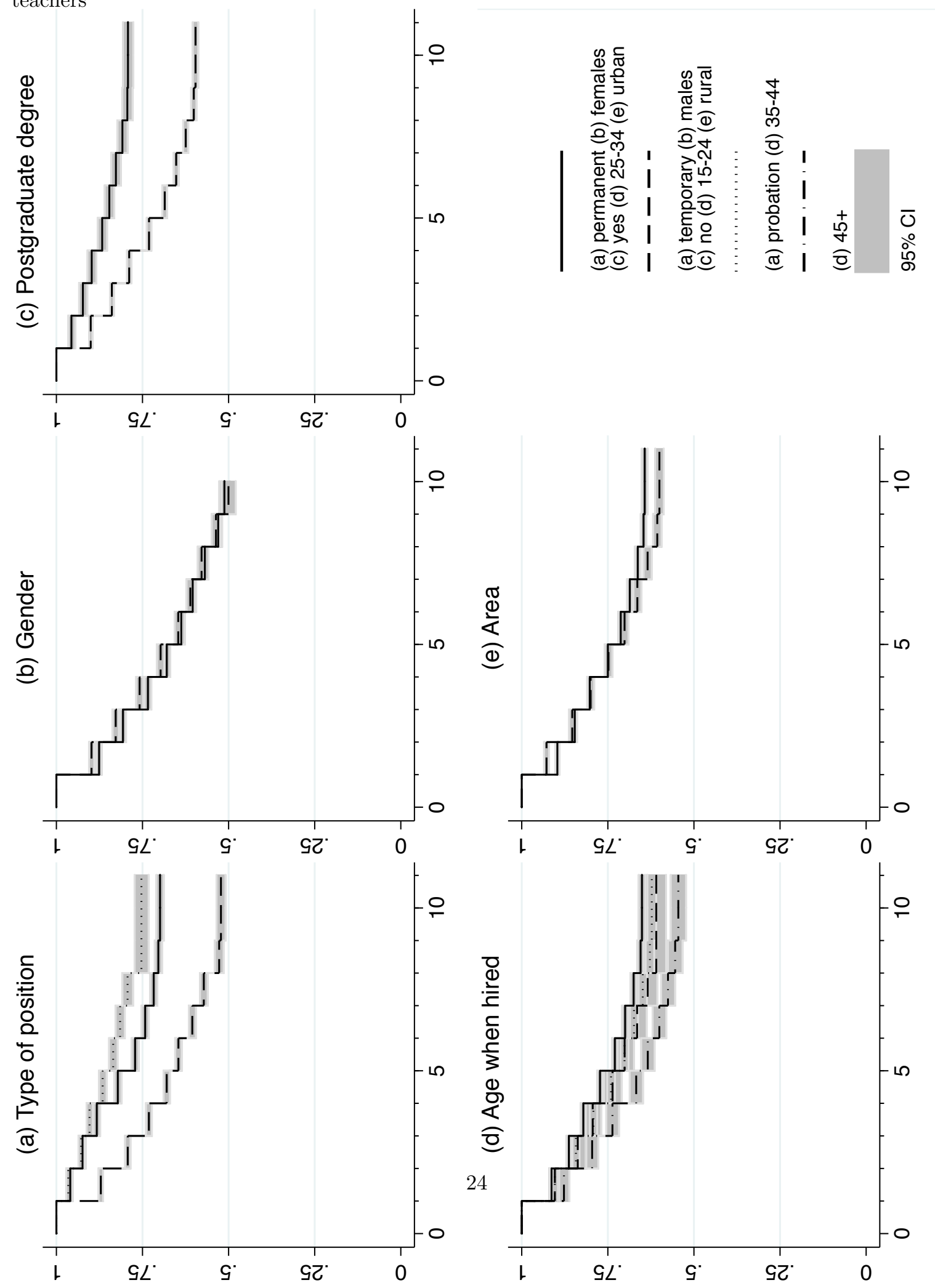
expected permanence in the profession is non-monotonic, with the highest-scoring teachers showing lower survival rates with respect to their colleagues in the two middle quartiles. The analysis on score deciles in the Appendix (Figure A.5) confirms this finding. It thus appears that even the more skill-rewarding career structure offered by the New Regulation has not yet succeeded at making the teaching profession as attractive to top-performers as for their more average colleagues.

\section{Robustness checks}

\subsection{Additional time controls, and one teacher per subject}

In this table we repeat our main estimation (Table 3) with additional cohort and experience. In particular, we add two different sets of hiring cohort dummies (Columns 1 and 3) and limit the sample to school-year-subject cells who do not contain any teachers with less than 5 or more than 40 years of experience (Columns 2 and 4). In these specifications, the effect of New-Regulation Passed teachers reduces between $20 \%$ and $43 \%$ with respect to our main results, remaining statistically significant throughout. The effect of New-Regulation Non-Passed teachers instead proves less robust and cannot be distinguished from zero. The final exercise (Column 5) uses only school-year-subject cells with only one teacher. 
Table 9: Additional time controls, limiting experience, 1 teacher per subject

\begin{tabular}{|c|c|c|c|c|c|}
\hline & Cohorts I & $\begin{array}{l}\text { Cohorts I + } \\
\text { limit exper. }\end{array}$ & Cohorts II & $\begin{array}{c}\text { Cohorts II + } \\
\text { limit exper. }\end{array}$ & 1 teacher \\
\hline Share New Reg. Passed & $\begin{array}{l}0.113^{*} \\
(0.044)\end{array}$ & $\begin{array}{l}0.127^{* *} \\
(0.042)\end{array}$ & $\begin{array}{r}0.145^{*} \\
(0.071)\end{array}$ & $\begin{array}{l}0.162^{*} \\
(0.070)\end{array}$ & $\begin{array}{c}0.103 \\
(0.068)\end{array}$ \\
\hline Share New Reg. Not Passed & $\begin{array}{c}0.056 \\
(0.051)\end{array}$ & $\begin{array}{c}0.070 \\
(0.050)\end{array}$ & $\begin{array}{c}0.134 \\
(0.095)\end{array}$ & $\begin{array}{c}0.157 \\
(0.094)\end{array}$ & $\begin{array}{c}0.029 \\
(0.081)\end{array}$ \\
\hline Experience & $\begin{array}{l}0.032^{\text {*** }} \\
(0.005)\end{array}$ & $\begin{array}{l}0.034^{* * *} \\
(0.005)\end{array}$ & $\begin{array}{l}0.057^{* * *} \\
(0.012)\end{array}$ & $\begin{array}{l}0.045^{* * *} \\
(0.011)\end{array}$ & $\begin{array}{r}0.017^{*} \\
(0.008)\end{array}$ \\
\hline 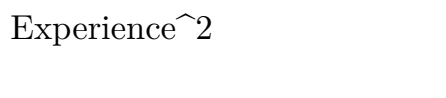 & $\begin{array}{l}-0.001^{* * *} \\
(0.000)\end{array}$ & $\begin{array}{l}-0.001 * * * \\
(0.000)\end{array}$ & $\begin{array}{l}-0.001^{* * *} \\
(0.000)\end{array}$ & $\begin{array}{l}-0.001 * * * \\
(0.000)\end{array}$ & $\begin{array}{l}-0.000^{*} \\
(0.000)\end{array}$ \\
\hline Age & $\begin{array}{l}0.028^{* * *} \\
(0.009)\end{array}$ & $\begin{array}{l}0.028^{* * *} \\
(0.009)\end{array}$ & $\begin{array}{c}0.021 \\
(0.020)\end{array}$ & $\begin{array}{c}0.022 \\
(0.020)\end{array}$ & $\begin{array}{c}0.013 \\
(0.013)\end{array}$ \\
\hline $\mathrm{Age}^{\wedge} 2$ & $\begin{array}{l}-0.000^{* * *} \\
(0.000)\end{array}$ & $\begin{array}{l}-0.000^{* * *} \\
(0.000)\end{array}$ & $\begin{array}{c}-0.000 \\
(0.000)\end{array}$ & $\begin{array}{l}-0.000 \\
(0.000)\end{array}$ & $\begin{array}{l}-0.000 \\
(0.000)\end{array}$ \\
\hline Share Postgrad degree & $\begin{array}{c}0.024 \\
(0.024)\end{array}$ & $\begin{array}{c}0.023 \\
(0.024)\end{array}$ & $\begin{array}{l}0.006 \\
(0.035)\end{array}$ & $\begin{array}{c}0.002 \\
(0.035)\end{array}$ & $\begin{array}{c}0.069 \\
(0.042)\end{array}$ \\
\hline Share hired post 1980 & $\begin{array}{c}-0.119^{*} \\
(0.054)\end{array}$ & & $\begin{array}{l}-0.105 \\
(0.076)\end{array}$ & & \\
\hline Share hired post 1990 & $\begin{array}{c}-0.111^{*} \\
(0.053)\end{array}$ & & $\begin{array}{c}-0.023 \\
(0.081)\end{array}$ & & \\
\hline Share hired post 2000 & $\begin{array}{c}0.064 \\
(0.053)\end{array}$ & & $\begin{array}{r}0.180^{*} \\
(0.083)\end{array}$ & & \\
\hline Share hired post 1985 & & $\begin{array}{c}-0.146^{*} \\
(0.057)\end{array}$ & & $\begin{array}{l}-0.134 \\
(0.081)\end{array}$ & \\
\hline Share hired post 1995 & & $\begin{array}{c}0.006 \\
(0.037)\end{array}$ & & $\begin{array}{c}0.003 \\
(0.051)\end{array}$ & \\
\hline Share hired post 2005 & & $\begin{array}{c}0.071 \\
(0.043)\end{array}$ & & $\begin{array}{c}0.124 \\
(0.067)\end{array}$ & \\
\hline Subject dummies & $\checkmark$ & $\checkmark$ & $\checkmark$ & $\checkmark$ & $\checkmark$ \\
\hline Subject-specific trends & $\checkmark$ & $\checkmark$ & $\checkmark$ & $\checkmark$ & $\checkmark$ \\
\hline Mean(y) & $\begin{array}{c}43.33 \\
3.292\end{array}$ & $\begin{array}{c}43.33 \\
3292\end{array}$ & $\begin{array}{c}43.35 \\
3.346\end{array}$ & $\begin{array}{c}43.35 \\
3.346\end{array}$ & $\begin{array}{l}42.58 \\
3.324\end{array}$ \\
\hline $\begin{array}{l}\text { sd(y) } \\
\text { N.obs }\end{array}$ & $\begin{array}{r}3.292 \\
151,178\end{array}$ & $\begin{array}{r}3.292 \\
151,178\end{array}$ & $\begin{array}{r}3.346 \\
74,114\end{array}$ & $\begin{array}{r}3.346 \\
74,114\end{array}$ & $\begin{array}{r}3.324 \\
62,621\end{array}$ \\
\hline N.groups & 29,609 & 29,609 & 25,055 & 25,055 & 25,860 \\
\hline $\mathrm{R}$-squared & 0.79 & 0.79 & 0.83 & 0.83 & 0.80 \\
\hline
\end{tabular}

Note: SE clustered by school in parentheses. Each observation is subject ' $\mathrm{s}$ ' in school ' $\mathrm{i}$ ' in year 'y'. School-year fixed effects in all columns. ${ }^{*} \mathrm{p}<0.05,{ }^{* *} \mathrm{p}<0.01,{ }^{* * *} \mathrm{p}<0.001$ 


\section{Conclusion}

In this paper we estimate the effect that the 2002 reform of the public teacher career has had on the performance of Colombian high school students. The reform introduced exam-based selection at entry and a set of further quality incentives for teachers. We find positive and significant effects of New Regulation teachers on student test scores, in a magnitude of around $6 \%$ of a subject standard deviation increase in test scores when the share of these teachers goes from 0 to 1 in a given subject in a given school and year. When the share of New Regulation teachers in a subject is still low, increasing it yields a marginal effect up to three times as high the average one, and higher than average gains are also to be found in larger and more educated teacher groups.

After having explored heterogeneities in the effect and survival patterns of teachers in the education system, we are induced to conclude that the main channel through which the reform has brought about its positive results on student performance is the selection of teacher candidates at entry, which has been quite tight as around two thirds of initial candidates do not reach sufficiency at the exam stage. Selection at the initial probation period and selection on tenured teachers may also be contributing to raise the quality of surviving educators, but we are currently unable to quantify these contributions due to the absence of data on reasons for exit from teacher records.

Our analysis has also exposed a less successful side of the post-reform setting, namely the fact that around $30 \%$ of the New Regulation teachers recorded in the system over the 2008-2013 period are not fully accredited as they have not successfully passed the entry exam. They are employed in temporary positions but seem to persist in this status sometimes over several years. The intention of the law in allowing these types of temporary employments was to deal with exceptional circumstances in which vacancies need to be filled but no eligible candidates are at hand, but the dimension of the phenomenon appears to be larger than what would be justified by exceptional circumstances.

In terms of future research, we believe that it shall be highly interesting to look at New Regulation teachers in some year's time, when their employment histories will be longer and more informative on the incentives they face over their careers. The availability of data on the reasons for dismissal or voluntary departure, as well as data on voluntary formation courses attended by teachers, would be of immense value towards understanding to which extent the permanent evaluation aspect of the reform is effectively operating.

\section{References}

Raj Chetty, John N. Friedman, and Jonah E. Rockoff. Measuring the impacts of teacher i: Evaluating bias in teacher value-added estimates. American Economic Review, 104(9):2633-2679, 2014.

Jesus Duarte. Política y educación: Tentaciones particularistas en la educación latinoamericana. Economía Política de las Reformas Educativas en América Latina, 2001. 
Jesus Duarte. Educación pública y clientelismo en Colombia. Universidad de Antioquia, Medellín, 2003.

David N. Figlio. Can public schools buy better-qualified teachers. Industrial and Labor Relations Review, 55:686, 2001. URL http://heinonline.org/HOL/Page?handle=hein.journals/ialrr55\& id=688\&div=\&collection=journals.

Grupo GEARD. Explicación de las etapas del concurso para ingreso a la carrera docente 2013, 2013. URL https://www. youtube. com/watch?v=r7iyL03EvZA.

Robert James Gordon, Thomas J. Kane, and Douglas Staiger. Identifying effective teachers using performance on the job. Brookings Institution Washington, DC, 2006. URL https: //books . google.com/books?hl=en\&lr=\&id=n0ntgoDT4tkC\&oi=fnd\&pg=PA189\&dq= identifying+effective+teachers+using+performance+on+the+job\&ots=173g7bXFYN\&sig= nLCKr8AZkGWYAZJz3E_RVrQEmoo.

Eric A. Hanushek. School policy: implications of recent research for human capital investments in south asia and other developing countries. Education Economics, 17(3):291-313, 2009. doi: 10.1080/09645290903142585. URL http://www.tandfonline.com/doi/pdf/10.1080/ 09645290903142585.

Eric A. Hanushek and Steven G. Rivkin. The distribution of teacher quality and implications for policy. SSRN Scholarly Paper ID 2139257, Social Science Research Network, Rochester, NY, July 2012. URL http://hanushek.stanford.edu/sites/default/files/publications/Hanushek\% 2BRivkin $\% 202012 \% 20$ AnnRevEcon $\% 204$. pdf.

Eric A. Hanushek and Ludger Woessmann. Do better schools lead to more growth? cognitive skills, economic outcomes, and causation. Journal of Economic Growth, 17(4):267-321, July 2012. ISSN 1381-4338, 1573-7020. doi: 10.1007/s10887-012-9081-x. URL http://link.springer.com/ article/10.1007/s10887-012-9081-x.

Eric A. Hanushek, John F. Kain, and Steven G. Rivkin. Why public schools lose teachers. Journal of human resources, 39(2):326-354, 2004. URL http://jhr.uwpress.org/content/XXXIX/2/326. short.

Thomas J. Kane, Jonah E. Rockoff, and Douglas O. Staiger. What does certification tell us about teacher effectiveness? evidence from new york city. Economics of Education Review, 27(6):615631, December 2008. ISSN 0272-7757. doi: 10.1016/j.econedurev.2007.05.005. URL http://www . sciencedirect.com/science/article/pii/S0272775707000775.

MEN. Decreto 3982 de 2006. Ministerio de Educación Nacional; Diario Oficial, 46449, November 2006.

MEN. Estatuto de profesionalizacion docente - informacion general y avances - abril de 2008, April 2008. URL http://www.colombiaaprende.edu.co/html/productos/1685/articles-161031_ archivo_3.pdf.

MEN. Por meritocracia se seleccionarán 20.610 docentes, directivos docentes y etnoeducadores. Tech- 
nical report, Ministerio de Educación Nacional; http://www.mineducacion.gov.co/cvn/1665/w3article-312669.html [21 Jan 2015], October 2012. URL http://www.mineducacion.gov.co/cvn/ 1665/w3-article-312669.html.

MEN. Estadísticas concursos 2004 - 2009. Technical report, Ministerio de Educación Nacional; http://www.mineducacion.gov.co/1621/w3-propertyvalue-48463.html [20 Jan 2015], May 2013a. URL http://www .mineducacion.gov.co/1621/w3-propertyvalue-48463.html.

MEN. ¿quiénes se reubican salarialmente o ascienden? Technical report, Ministerio de Educación Nacional; http://www.mineducacion.gov.co/proyectos/1737/w3-article-309814.html [22 Jan 2015], June 2013b. URL http://www.mineducacion.gov.co/proyectos/1737/w3-article-309814. html.

F. J. Murillo, A. González, and M. Rizo. Evaluación del desempeño y carrera profesional docente. una panorámica de américa y europa. Santiago de Chile: UNESCO. [2 $2^{a}$ Ed. Revisada], 2007.

OECD. Education in Colombia. Reviews of National Policies for Education. OECD Publishing, Paris, 2016.

Alejandro Ome. The effects of meritocracy for teachers in colombia. INFORMES DE INVESTIGACIÓN 010260, FEDESARROLLO, 2012a.

Alejandro Ome. Salarios de los docentes públicos en colombia 1995-2010. COYUNTURA ECONÓMICA, 2012b. URL http://econpapers.repec.org/article/col000438/011643.htm.

Alejandro Ome. El estatuto de profesionalización docente: una primera evaluación. CUADERNOS DE FEDESARROLLO, FEDESARROLLO, May 2013. URL http://econpapers.repec.org/ paper/col000439/011553.htm.

Steven G. Rivkin, Eric A. Hanushek, and John F. Kain. Teachers, schools, and academic achievement. Econometrica, 73(2):417-458, 2005. ISSN 1468-0262. doi: 10.1111/j.1468-0262.2005.00584.x. URL http://www. econ.ucsb.edu/ jon/Econ230C/HanushekRivkin.pdf.

Jonah E. Rockoff. The impact of individual teachers on student achievement: Evidence from panel data. American Economic Review, 5(1):247-252, 2005. URL https://www0.gsb.columbia.edu/ faculty/jrockoff/rockoff_teachers_march_04.pdf.

Jonah E. Rockoff, Brian A. Jacob, Thomas J. Kane, and Douglas O. Staiger. Can you recognize an effective teacher when you recruit one? Education Finance and Policy, 6(1):43-74, January 2011. ISSN 1557-3060. doi: 10.1162/EDFP_a_00022. URL http://dx.doi.org/10.1162/EDFP_ a_00022.

Jeffrey Wooldridge. Econometric analysis of cross section and panel data. MIT Press, 2010. 


\section{A Data on the past entry contests}

Table A.1: Selectivity of the entry contests

\begin{tabular}{|c|c|c|c|c|c|}
\hline CONTESTS > & 1st (2004) & 2nd (2005) & 3rd (2006) & $4 \operatorname{th}(2009)$ & 5 th $(2013)$ \\
\hline N. of local authorities & 69 & 66 & 49 & 66 & 92 \\
\hline Vacancies & 50.947 & 23.355 & 14.579 & 25.392 & $?$ \\
\hline Candidates to exam & 140.541 & 134.090 & 109.487 & 228.985 & 301.589 \\
\hline Passed exam stage & $60.078(43 \%)$ & $32.720(24 \%)$ & $27.931(26 \%)$ & $66.687(29 \%)$ & $54.906(18 \%)$ \\
\hline Assigned to vacancy & $30.568(22 \%)$ & $14.092(11 \%)$ & $13.620(12 \%)$ & $39.468(17 \%)$ & $?$ \\
\hline
\end{tabular}

Note: all percentages are relative to 'Candidates to exam'

Source: MEN [2013] 


\section{B Details on career structure, salaries and education level of teachers}

Table A.2: Career structure of public school teachers, and 2008 pay scales

\begin{tabular}{|c|c|c|c|c|c|c|c|}
\hline \multicolumn{3}{|c|}{ Old Regulation (Dec. 2277 / 1979) } & \multicolumn{5}{|c|}{ New Regulation (Dec. 1278 / 2002) } \\
\hline Step & $\begin{array}{c}\text { Education } \\
\text { level required }\end{array}$ & 2008 salary & Level & Step & $\begin{array}{c}\text { Education } \\
\text { level required }\end{array}$ & \multicolumn{2}{|c|}{2008 salary } \\
\hline $\bar{A}$ & \multirow{3}{*}{$\begin{array}{l}\text { Secondary } \\
\text { school }\end{array}$} & 525.240 & \multirow{4}{*}{1} & $\overline{\mathrm{A}}$ & \multirow{4}{*}{$\begin{array}{c}\text { Postsecondary } \\
\text { specialization }\end{array}$} & \multicolumn{2}{|c|}{745.624} \\
\hline B & & 581.850 & & $\mathrm{~B}$ & & \multicolumn{2}{|c|}{1.014 .611} \\
\hline 1 & & 652.079 & & $\mathrm{C}$ & & \multicolumn{2}{|c|}{1.531 .186} \\
\hline 2 & \multirow{4}{*}{$\begin{array}{c}\text { Postsecondary } \\
\text { specialization }\end{array}$} & 675.922 & & $\mathrm{D}$ & & \multicolumn{2}{|c|}{1.759 .188} \\
\hline 3 & & 717.284 & \multirow{4}{*}{2} & $\mathrm{~A}$ & \multirow{4}{*}{$\begin{array}{c}\text { Undergraduate } \\
\text { degree }\end{array}$} & \multicolumn{2}{|c|}{938.340} \\
\hline 4 & & 745.600 & & $\mathrm{~B}$ & & \multicolumn{2}{|c|}{1.421 .428} \\
\hline 5 & & 792.628 & & $\mathrm{C}$ & & \multicolumn{2}{|c|}{1.834 .801} \\
\hline 6 & \multirow{8}{*}{$\begin{array}{c}\text { Undergraduate } \\
\text { degree }\end{array}$} & 838.439 & & $\mathrm{D}$ & & \multicolumn{2}{|c|}{1.980 .454} \\
\hline 7 & & 938.315 & \multirow{5}{*}{3} & & & Master dę & PhD deg. \\
\hline 8 & & 1.030 .680 & & A & \multirow{4}{*}{$\begin{array}{c}\text { Postgraduate } \\
\text { degree }\end{array}$} & 1.415 .933 & 1.721 .798 \\
\hline 9 & & 1.141 .779 & & B & & 1.772 .111 & 2.154 .919 \\
\hline 10 & & 1.250 .166 & & $\mathrm{C}$ & & 2.017 .127 & 2.452 .864 \\
\hline 11 & & 1.427 .513 & & $\mathrm{D}$ & & 2.140 .784 & 2.603 .232 \\
\hline 12 & & 1.698 .112 & & & & & \\
\hline 13 & & 1.879 .682 & & & & & \\
\hline 14 & $\begin{array}{l}\text { Postgraduate } \\
\text { degree }\end{array}$ & 2.140 .766 & & & & & \\
\hline
\end{tabular}

Source: compiled by the authors based on Decree 2277 / 1979, Decree 259 / 1981, Decree 626 / 2008, Decree 624 / 2008, MEN [2008]. Salaries in 2008 Colombian Pesos. The shaded steps are the possible entry steps for first-time teachers.

\section{Descriptive statistics}


Figure A.1: Education level of public school teachers

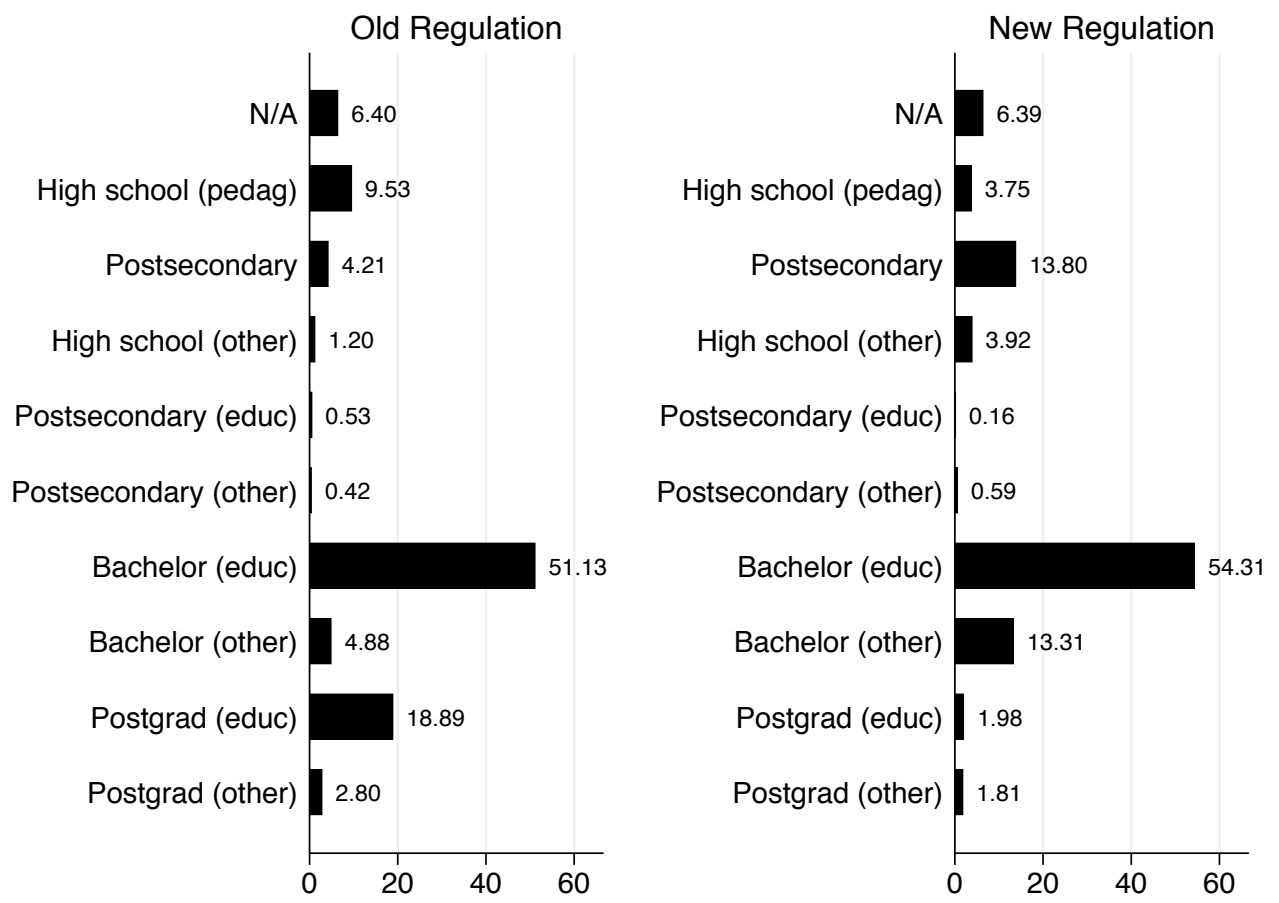

(a) All teachers
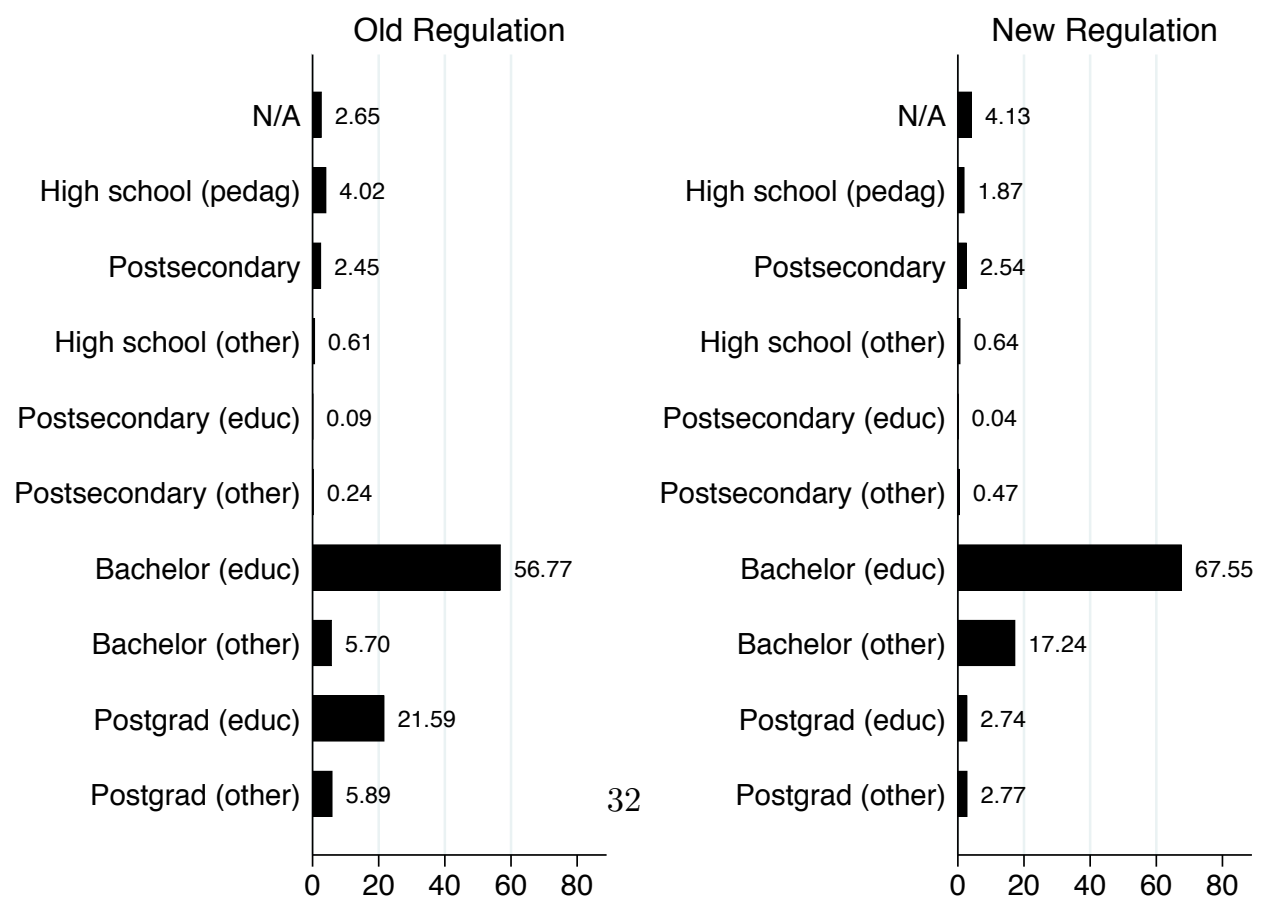

(b) Secondary school teachers only 
Table A.3: Descriptive statistics at school-year-subject level

\begin{tabular}{lccc}
\hline & Total & Within & Between \\
\hline Mean student score & 43.33 & & $(2.70)$ \\
Share New Regulation & $(3.29)$ & $(2.04)$ & $(0.33)$ \\
Share New Regulation Passed & 0.47 & $(0.30)$ & $(0.28)$ \\
Share New Regulation Not Passed & $(0.43)$ & $(0.31)$ & $(0.21)$ \\
Share Old Regulation & 0.34 & $(0.22)$ & $(0.33)$ \\
Mean age & $0.13)$ & $(0.30)$ & $(5.83)$ \\
Mean experience & $(0.29)$ & $(6.31)$ & $(6.85)$ \\
Share postgraduate degree & 0.53 & $(0.43)$ & $(6.48)$ \\
& 44.20 & $(0.25)$ & $(0.24)$ \\
\hline N & $(8.31)$ & 12.49 & 151,178 \\
\hline
\end{tabular}

Note: Variable means and (standard deviations). Total, within-group and between group standard deviations, where a group is a school-year cell.

\section{New Regulation teachers as a single group}

In Table A.6 we repeat our main estimations considering New Regulation teachers as a single group, without distinguishing between those who have passed the entry contest and those who have not.

\section{E Heterogeneity Tables}

These tables are behind the graphical results of panels (a)-(e) in Figure 2 in Section 6.2. 
Table A.4: Individual-level teacher descriptives

\begin{tabular}{|c|c|c|c|c|c|}
\hline & $\begin{array}{c}\text { All } \\
\text { teachers }\end{array}$ & $\begin{array}{c}\text { Old } \\
\text { Regulation }\end{array}$ & $\begin{array}{c}\text { All New } \\
\text { Regulation }\end{array}$ & $\begin{array}{c}\text { New Regul. } \\
\text { Passed }\end{array}$ & $\begin{array}{l}\text { New Regul } \\
\text { Not Passed }\end{array}$ \\
\hline Age & $\begin{array}{c}45.80 \\
(10.06)\end{array}$ & $\begin{array}{l}50.22 \\
(7.59)\end{array}$ & $\begin{array}{l}37.26 \\
(8.65)\end{array}$ & $\begin{array}{l}37.09 \\
(8.74)\end{array}$ & $\begin{array}{l}37.82 \\
(8.35)\end{array}$ \\
\hline Experience & $\begin{array}{c}15.57 \\
(11.75)\end{array}$ & $\begin{array}{l}21.92 \\
(9.38)\end{array}$ & $\begin{array}{c}3.30 \\
(2.50)\end{array}$ & $\begin{array}{c}3.53 \\
(2.51)\end{array}$ & $\begin{array}{c}2.55 \\
(2.31)\end{array}$ \\
\hline Female & $\begin{array}{c}0.66 \\
(0.47)\end{array}$ & $\begin{array}{c}0.67 \\
(0.47)\end{array}$ & $\begin{array}{c}0.63 \\
(0.48)\end{array}$ & $\begin{array}{c}0.61 \\
(0.49)\end{array}$ & $\begin{array}{c}0.70 \\
(0.46)\end{array}$ \\
\hline Postgrad degree & $\begin{array}{c}0.20 \\
(0.40)\end{array}$ & $\begin{array}{c}0.26 \\
(0.44)\end{array}$ & $\begin{array}{c}0.09 \\
(0.28)\end{array}$ & $\begin{array}{c}0.10 \\
(0.30)\end{array}$ & $\begin{array}{c}0.04 \\
(0.19)\end{array}$ \\
\hline Experience 5-40yrs & $\begin{array}{c}0.75 \\
(0.43)\end{array}$ & $\begin{array}{c}0.98 \\
(0.15)\end{array}$ & $\begin{array}{c}0.31 \\
(0.46)\end{array}$ & $\begin{array}{c}0.35 \\
(0.48)\end{array}$ & $\begin{array}{c}0.20 \\
(0.40)\end{array}$ \\
\hline Age when hired & $\begin{array}{l}30.23 \\
(8.12)\end{array}$ & $\begin{array}{l}28.30 \\
(7.19)\end{array}$ & $\begin{array}{l}33.96 \\
(8.49)\end{array}$ & $\begin{array}{l}33.55 \\
(8.49)\end{array}$ & $\begin{array}{l}35.28 \\
(8.37)\end{array}$ \\
\hline Rural area & $\begin{array}{c}0.30 \\
(0.46)\end{array}$ & $\begin{array}{c}0.23 \\
(0.42)\end{array}$ & $\begin{array}{c}0.43 \\
(0.49)\end{array}$ & $\begin{array}{c}0.39 \\
(0.49)\end{array}$ & $\begin{array}{c}0.54 \\
(0.50)\end{array}$ \\
\hline Permanent position & $\begin{array}{c}0.85 \\
(0.36)\end{array}$ & $\begin{array}{c}0.99 \\
(0.09)\end{array}$ & $\begin{array}{c}0.58 \\
(0.49)\end{array}$ & $\begin{array}{c}0.70 \\
(0.46)\end{array}$ & $\begin{array}{c}0.19 \\
(0.39)\end{array}$ \\
\hline Temporary position & $\begin{array}{c}0.11 \\
(0.32)\end{array}$ & $\begin{array}{c}0.01 \\
(0.08)\end{array}$ & $\begin{array}{c}0.32 \\
(0.47)\end{array}$ & $\begin{array}{c}0.19 \\
(0.39)\end{array}$ & $\begin{array}{c}0.74 \\
(0.44)\end{array}$ \\
\hline Probation position & $\begin{array}{c}0.03 \\
(0.18)\end{array}$ & $\begin{array}{c}0.00 \\
(0.04)\end{array}$ & $\begin{array}{c}0.09 \\
(0.29)\end{array}$ & $\begin{array}{c}0.10 \\
(0.30)\end{array}$ & $\begin{array}{c}0.07 \\
(0.25)\end{array}$ \\
\hline Most recent test score & & & & $\begin{array}{l}63.69 \\
(3.87) \\
\end{array}$ & $\begin{array}{l}55.32 \\
(3.52) \\
\end{array}$ \\
\hline $\mathrm{N}$ & 1743,339 & 1149,239 & 594,100 & 452,493 & 141,607 \\
\hline $\mathrm{N}$ teachers & 360,644 & 214,920 & 145,724 & 108,735 & 36,989 \\
\hline
\end{tabular}

Note: Variable means and (standard deviations). 
Table A.5: Individual-level teacher descriptives - Secondary school teachers only

\begin{tabular}{|c|c|c|c|c|c|}
\hline & $\begin{array}{c}\text { All } \\
\text { teachers }\end{array}$ & $\begin{array}{c}\text { Old } \\
\text { Regulation }\end{array}$ & $\begin{array}{c}\text { All New } \\
\text { Regulation }\end{array}$ & $\begin{array}{c}\text { New Regul. } \\
\text { Passed }\end{array}$ & $\begin{array}{l}\text { New Regul } \\
\text { Not Passed }\end{array}$ \\
\hline Age & $\begin{array}{l}45.45 \\
(9.99)\end{array}$ & $\begin{array}{l}50.90 \\
(7.20)\end{array}$ & $\begin{array}{l}37.47 \\
(7.93)\end{array}$ & $\begin{array}{l}37.34 \\
(7.81)\end{array}$ & $\begin{array}{l}37.92 \\
(8.29)\end{array}$ \\
\hline Experience & $\begin{array}{c}14.13 \\
(11.43)\end{array}$ & $\begin{array}{l}21.61 \\
(8.83)\end{array}$ & $\begin{array}{c}3.18 \\
(2.50)\end{array}$ & $\begin{array}{c}3.44 \\
(2.51)\end{array}$ & $\begin{array}{c}2.33 \\
(2.23)\end{array}$ \\
\hline Female & $\begin{array}{c}0.55 \\
(0.50)\end{array}$ & $\begin{array}{c}0.57 \\
(0.50)\end{array}$ & $\begin{array}{c}0.54 \\
(0.50)\end{array}$ & $\begin{array}{c}0.51 \\
(0.50)\end{array}$ & $\begin{array}{c}0.62 \\
(0.49)\end{array}$ \\
\hline Postgrad degree & $\begin{array}{c}0.23 \\
(0.42)\end{array}$ & $\begin{array}{c}0.32 \\
(0.47)\end{array}$ & $\begin{array}{c}0.10 \\
(0.30)\end{array}$ & $\begin{array}{c}0.11 \\
(0.32)\end{array}$ & $\begin{array}{c}0.04 \\
(0.20)\end{array}$ \\
\hline Experience 5-40yrs & $\begin{array}{c}0.71 \\
(0.46)\end{array}$ & $\begin{array}{c}0.98 \\
(0.13)\end{array}$ & $\begin{array}{c}0.30 \\
(0.46)\end{array}$ & $\begin{array}{c}0.34 \\
(0.47)\end{array}$ & $\begin{array}{c}0.17 \\
(0.38)\end{array}$ \\
\hline Age when hired & $\begin{array}{l}31.32 \\
(7.55)\end{array}$ & $\begin{array}{l}29.29 \\
(6.78)\end{array}$ & $\begin{array}{l}34.29 \\
(7.64)\end{array}$ & $\begin{array}{l}33.90 \\
(7.40)\end{array}$ & $\begin{array}{l}35.60 \\
(8.27)\end{array}$ \\
\hline Rural area & $\begin{array}{c}0.21 \\
(0.41)\end{array}$ & $\begin{array}{c}0.14 \\
(0.34)\end{array}$ & $\begin{array}{c}0.33 \\
(0.47)\end{array}$ & $\begin{array}{c}0.29 \\
(0.46)\end{array}$ & $\begin{array}{c}0.44 \\
(0.50)\end{array}$ \\
\hline Permanent position & $\begin{array}{c}0.83 \\
(0.38)\end{array}$ & $\begin{array}{l}1.00 \\
(0.07)\end{array}$ & $\begin{array}{c}0.58 \\
(0.49)\end{array}$ & $\begin{array}{c}0.72 \\
(0.45)\end{array}$ & $\begin{array}{c}0.13 \\
(0.33)\end{array}$ \\
\hline Temporary position & $\begin{array}{c}0.14 \\
(0.35)\end{array}$ & $\begin{array}{c}0.00 \\
(0.07)\end{array}$ & $\begin{array}{c}0.34 \\
(0.47)\end{array}$ & $\begin{array}{c}0.20 \\
(0.40)\end{array}$ & $\begin{array}{c}0.83 \\
(0.38)\end{array}$ \\
\hline Probation position & $\begin{array}{c}0.03 \\
(0.17)\end{array}$ & $\begin{array}{c}0.00 \\
(0.01)\end{array}$ & $\begin{array}{c}0.07 \\
(0.26)\end{array}$ & $\begin{array}{c}0.08 \\
(0.27)\end{array}$ & $\begin{array}{c}0.04 \\
(0.20)\end{array}$ \\
\hline Most recent test score & & & & $\begin{array}{l}64.11 \\
(3.96)\end{array}$ & $\begin{array}{l}55.38 \\
(3.59)\end{array}$ \\
\hline $\mathrm{N}$ & 437,570 & 259,850 & 177,720 & 136,974 & 40,746 \\
\hline $\mathrm{N}$ teachers & 118,117 & 64,883 & 53,234 & 40,339 & 12,895 \\
\hline
\end{tabular}


Table A.6: The effect of New Regulation teachers on student performance

\begin{tabular}{|c|c|c|c|c|c|}
\hline & (1) & $(2)$ & $(3)$ & $(4)$ & $(5)$ \\
\hline Share New Regulation & $\begin{array}{l}-0.95^{* * *} \\
(0.05)\end{array}$ & $\begin{array}{l}0.63^{* * *} \\
(0.07)\end{array}$ & $\begin{array}{l}0.09^{* *} \\
(0.03)\end{array}$ & $\begin{array}{l}0.19^{* * * *} \\
(0.04)\end{array}$ & $\begin{array}{l}0.19^{* * *} \\
(0.04)\end{array}$ \\
\hline Age & & $\begin{array}{l}0.05^{* * *} \\
(0.01)\end{array}$ & $\begin{array}{l}0.03^{* * *} \\
(0.01)\end{array}$ & $\begin{array}{l}0.03^{* * *} \\
(0.01)\end{array}$ & $\begin{array}{l}0.03^{* * *} \\
(0.01)\end{array}$ \\
\hline $\mathrm{Age}^{\wedge} 2$ & & $\begin{array}{l}-0.00 * * * \\
(0.00)\end{array}$ & $\begin{array}{l}-0.00^{* * *} \\
(0.00)\end{array}$ & $\begin{array}{l}-0.00^{* * *} \\
(0.00)\end{array}$ & $\begin{array}{l}-0.00 * * * \\
(0.00)\end{array}$ \\
\hline Experience & & $\begin{array}{l}0.15^{* * *} \\
(0.01)\end{array}$ & $\begin{array}{l}0.03^{* * *} \\
(0.00)\end{array}$ & $\begin{array}{l}0.03^{* * *} \\
(0.00)\end{array}$ & $\begin{array}{l}0.03^{* * *} \\
(0.00)\end{array}$ \\
\hline Experience 2 & & $\begin{array}{l}-0.00 * * * \\
(0.00)\end{array}$ & $\begin{array}{l}-0.00^{* * *} \\
(0.00)\end{array}$ & $\begin{array}{l}-0.00^{* * *} \\
(0.00)\end{array}$ & $\begin{array}{l}-0.00^{* * *} \\
(0.00)\end{array}$ \\
\hline Share postgrad degree & & $\begin{array}{l}1.00^{* * *} \\
(0.06)\end{array}$ & $\begin{array}{c}0.01 \\
(0.02)\end{array}$ & $\begin{array}{c}0.02 \\
(0.02)\end{array}$ & $\begin{array}{c}0.02 \\
(0.02)\end{array}$ \\
\hline Subject-specific trends & & & & & $\checkmark$ \\
\hline Subject FE & $\checkmark$ & $\checkmark$ & $\checkmark$ & $\checkmark$ & $\checkmark$ \\
\hline School FE & & & $\checkmark$ & $\checkmark$ & $\checkmark$ \\
\hline Year FE & $\checkmark$ & $\checkmark$ & $\checkmark$ & $\checkmark$ & $\checkmark$ \\
\hline School-year FE & & & & $\checkmark$ & $\checkmark$ \\
\hline Mean $(y)$ & 43.33 & 43.33 & 43.33 & 43.33 & 43.33 \\
\hline $\operatorname{sd}(y)$ & 3.29 & 3.29 & 3.29 & 3.29 & 3.29 \\
\hline N.obs & 151,178 & 151,178 & 151,178 & 151,178 & 151,178 \\
\hline N.groups & & & 5,969 & 29,609 & 29,609 \\
\hline R-squared & 0.17 & 0.19 & 0.68 & 0.79 & 0.79 \\
\hline
\end{tabular}

Note: SE clustered by school in parentheses. Each observation is subject 's' in school 'i' in year ' $y$ '. No fixed effects in columns (1) and (2), school fixed effects in column (3), school-year fixed effects in columns (4) and (5). ${ }^{*} \mathrm{p}<0.05,{ }^{* *} \mathrm{p}<0.01,{ }^{* * *} \mathrm{p}<0.001$ 
Table A.7: Interaction with number of teachers in the year-subject

\begin{tabular}{|c|c|c|}
\hline & \multicolumn{2}{|c|}{ Student test scores } \\
\hline Share New-R. Passed (SNP) & $0.106^{* *}$ & $(0.038)$ \\
\hline Share New-R. Not Passed & 0.071 & $(0.044)$ \\
\hline 2 teachers & 0.017 & $(0.023)$ \\
\hline 3 teachers & $0.113^{* * *}$ & $(0.032)$ \\
\hline 4 teachers & $0.192^{* * *}$ & $(0.036)$ \\
\hline 5 teachers & $0.205^{* * *}$ & $(0.041)$ \\
\hline 6 teachers & $0.265^{* * *}$ & $(0.049)$ \\
\hline 7 teachers & $0.296^{* * *}$ & $(0.055)$ \\
\hline 8 teachers & $0.321^{* * *}$ & $(0.066)$ \\
\hline 9 teachers & $0.462^{* * *}$ & $(0.085)$ \\
\hline 10 teachers & $0.447^{* * *}$ & $(0.090)$ \\
\hline 11 teachers & $0.474^{* * *}$ & $(0.105)$ \\
\hline 2 teachers $* \mathrm{SNP}$ & 0.067 & $(0.045)$ \\
\hline 3 teachers $* \mathrm{SNP}$ & $0.165^{* *}$ & $(0.062)$ \\
\hline 4 teachers $* \mathrm{SNP}$ & $0.184^{*}$ & $(0.073)$ \\
\hline 5 teachers $* \mathrm{SNP}$ & $0.407^{* * *}$ & $(0.091)$ \\
\hline 6 teachers $* \mathrm{SNP}$ & $0.482^{* * *}$ & $(0.108)$ \\
\hline 7 teachers $*$ SNP & $0.604^{* * *}$ & $(0.137)$ \\
\hline 8 teachers $*$ SNP & $0.593^{* * *}$ & $(0.170)$ \\
\hline 9 teachers $*$ SNP & $0.638^{* *}$ & $(0.201)$ \\
\hline 10 teachers $*$ SNP & 0.495 & $(0.262)$ \\
\hline 11 teachers $*$ SNP & 0.533 & $(0.279)$ \\
\hline Age, experience, postgrad & $\checkmark$ & \\
\hline Subject FE & $\checkmark$ & \\
\hline School FE & $\checkmark$ & \\
\hline Year FE & $\checkmark$ & \\
\hline School-year FE & $\checkmark$ & \\
\hline Subject-specific trends & $\checkmark$ & \\
\hline $\operatorname{Mean}(\mathrm{y})$ & 43.30 & \\
\hline $\operatorname{sd}(y)$ & 3.29 & \\
\hline N.obs & 149,183 & \\
\hline N.groups & 29,604 & \\
\hline R-squared & 0.79 & \\
\hline
\end{tabular}

Note: SE clustered by school in parentheses. Each observation is subject ' $\mathrm{s}$ ' in school ' $\mathrm{i}$ ' in year ' $\mathrm{y}$ '. ${ }^{*} \mathrm{p}<0.05,{ }^{* *} \mathrm{p}<0.01,{ }^{* * *} \mathrm{p}<0.001$
Table A.8: Own interactions of 'Share NewRegulation Passed' in the year-subject

\begin{tabular}{lcc}
\hline & Student test scores \\
\hline Share New-R. Passed (SNP) & $0.755^{* * *}$ & $(0.186)$ \\
Share New-R. Not Passed & $0.111^{*}$ & $(0.044)$ \\
SNP ^2 & $-1.093^{*}$ & $(0.546)$ \\
SNP ^3 & 0.495 & $(0.372)$ \\
Age, experience, postgrad & $\checkmark$ & \\
\hline Subject FE & $\checkmark$ & \\
School FE & $\checkmark$ & \\
Year FE & $\checkmark$ & \\
School-year FE & $\checkmark$ & \\
Subject-specific trends & $\checkmark$ & \\
\hline Mean(y) & 43.30 & \\
sd(y) & 3.29 & \\
N.obs & 149,183 & \\
N.groups & 29,604 & \\
R-squared & 0.78 & \\
\hline
\end{tabular}

Note: SE clustered by school in parentheses. Each observation is subject ' $s$ ' in school ' $i$ ' in year ' $y$ '. ${ }^{*} \mathrm{p}<0.05,{ }^{* *} \mathrm{p}<0.01,{ }^{* * *} \mathrm{p}<0.001$ 
Table A.9: Interaction with average teacher score in the year-subject

\begin{tabular}{lcc}
\hline & \multicolumn{2}{c}{ Student test scores } \\
\hline Share New-R. Passed (SNP) & 0.163 & $(0.102)$ \\
Share New-R. Not Passed & 0.105 & $(0.065)$ \\
2nd quintile & $0.085^{*}$ & $(0.039)$ \\
3rd quintile & $0.105^{*}$ & $(0.044)$ \\
4th quintile & $0.181^{* * *}$ & $(0.046)$ \\
5th quintile & $0.168^{* * *}$ & $(0.046)$ \\
2nd quintile ${ }^{*}$ SNP & -0.125 & $(0.101)$ \\
3rd quintile * SNP & -0.066 & $(0.102)$ \\
4th quintile * SNP & -0.133 & $(0.105)$ \\
5th quintile * SNP & -0.102 & $(0.106)$ \\
Age, experience, postgrad & $\checkmark$ & \\
\hline Subject FE & $\checkmark$ & \\
School FE & $\checkmark$ & \\
Year FE & $\checkmark$ & \\
School-year FE & $\checkmark$ & \\
Subject-specific trends & $\checkmark$ & \\
\hline Mean(y) & 43.40 & \\
sd(y) & 3.24 & \\
N.obs & 99,108 & \\
N.groups & 27,435 & \\
R-squared & 0.81 & \\
\hline
\end{tabular}

Note: SE clustered by school in parentheses. Each observation is subject ' $\mathrm{s}$ ' in school ' $\mathrm{i}$ ' in year ' $\mathrm{y}$ '. ${ }^{*} \mathrm{p}<0.05,{ }^{* *} \mathrm{p}<0.01,{ }^{* * *} \mathrm{p}<0.001$
Table A.10: Interaction with share of postgraduate degree holders in the year-subject

\begin{tabular}{lcc}
\hline & Student test scores \\
\hline Share New-R. Passed (SNP) & $0.148^{* * *}$ & $(0.037)$ \\
Share New-R. Not Passed & $0.103^{*}$ & $(0.044)$ \\
Postgrad share $(0,0.5]$ & $0.064^{* *}$ & $(0.025)$ \\
Postgrad share $(0.5,1)$ & $0.165^{* * *}(0.036)$ \\
Postgrad share = 1 & 0.001 & $(0.028)$ \\
Postgrad share $(0,0.5]^{*}$ SNP & $0.210^{* * *}$ & $(0.053)$ \\
Postgrad share $(0.5,1)^{*}$ SNP & $0.374^{* * *}$ & $(0.112)$ \\
Postgrad share =1 * SNP & -0.028 & $(0.060)$ \\
Age, experience & $\checkmark$ & \\
\hline Subject FE & $\checkmark$ & \\
School FE & $\checkmark$ & \\
Year FE & $\checkmark$ & \\
School-year FE & $\checkmark$ & \\
Subject-specific trends & $\checkmark$ & \\
\hline Mean(y) & 43.30 & \\
sd(y) & 3.29 & \\
N.obs & 149,183 & \\
N.groups & 29,604 & \\
R-squared & 0.78 & \\
\hline
\end{tabular}

Note: SE clustered by school in parentheses. Each observation is subject 's' in school ' $\mathrm{i}$ ' in year ' $\mathrm{y}$ '. * $\mathrm{p}<0.05,{ }^{* *} \mathrm{p}<0.01,{ }^{* * *} \mathrm{p}<0.001$ 
Table A.11: Interaction with subject dummies

\begin{tabular}{lcc}
\hline & Student test scores \\
\hline Share New-R. Passed (SNP) & $0.157^{* * *}(0.045)$ \\
Share New-R. Not Passed & $0.143^{* *}(0.044)$ \\
Social Sciences & $-0.592^{* * *}(0.022)$ \\
Spanish & $0.936^{* * *}(0.022)$ \\
English & $-2.766^{* * *}(0.037)$ \\
Mathematics & $-0.884^{* * *}(0.031)$ \\
Chemistry & $0.151^{* * *}(0.026)$ \\
Physics & $-1.092^{* * *}(0.038)$ \\
Philosophy & $-4.271^{* * *}(0.037)$ \\
Social Sciences * SNP & 0.073 & $(0.054)$ \\
Spanish * SNP & 0.081 & $(0.052)$ \\
English * SNP & -0.055 & $(0.069)$ \\
Mathematics * SNP & $0.191^{* *}$ & $(0.062)$ \\
Chemistry * SNP & 0.053 & $(0.053)$ \\
Physics * SNP & 0.090 & $(0.069)$ \\
Philosophy $*$ SNP & $-0.217^{* *}$ & $(0.073)$ \\
Age, experience, postgrad & $\checkmark$ & \\
\hline School FE & $\checkmark$ & \\
Year FE & $\checkmark$ & \\
School-year FE & $\checkmark$ & \\
Subject-specific trends & $\checkmark$ & \\
\hline Mean(y) & \multicolumn{2}{l}{} \\
sd(y) & 43.30 & \\
N.obs & 3.29 & \\
N.groups & 149,183 & \\
R-squared & 29,604 & \\
\hline & 0.78 & \\
\hline
\end{tabular}

Note: Baseline subject is Natural Sciences. SE clustered by school in parentheses. Each observation is subject 's' in school ' $\mathrm{l}$ ' in year ' $\mathrm{y}$ '. ${ }^{*} \mathrm{p}<0.05,{ }^{* *}$ $\mathrm{p}<0.01,{ }^{* * *} \mathrm{p}<0.001$ 


\section{F Relationship between teacher skills and student perfor- mance}

\section{F.1 Derivation of the bias}

The student score $S S$ in a specific subject $i$ is determined by the total quality of the teachers teaching that subject $Q^{T}$. (1) is the population regression that I would ideally like to run in order to estimate $\beta$, the impact of teacher quality on student scores. Recall that we are operating at the within-school, within-school year level - I thus omit time and school indices. The variation used to estimate $\beta$ is solely within-school, within-school year, across subject variation.

$$
S S_{i}=\alpha+\beta Q_{i}^{T}+e_{i}
$$

The total teacher quality $Q^{T}$ is a weighted average of new-regulation teacher quality $Q^{N}$ and of old teacher quality $Q^{O}$, and the weights are their respective shares in subject $i, S^{N}$ and $1-S^{N}$ :

$$
Q_{i}^{T}=Q_{i}^{N} \cdot S_{i}^{N}+Q_{i}^{O} \cdot\left(1-S_{i}^{N}\right)
$$

We only observe the quality of new-regulation teachers $Q^{N}$, through their entry exam test scores. Thus, instead of (1), I am only able to estimate (2):

$$
S S_{i}=\alpha+\beta Q_{i}^{N}+e_{i}
$$

For the moment I am abstracting from the presence of new teachers that we were not able to match to their entry exam scores.

So the population regression coefficient $\beta$ is $\beta=\frac{\operatorname{cov}\left(S S_{i}, Q_{i}^{T}\right)}{\operatorname{var}\left(Q_{i}^{T}\right)}$ but instead I am estimating 


$$
\begin{aligned}
\hat{\beta}= & \frac{\operatorname{cov}\left(S S, Q^{N}\right)}{\operatorname{var}\left(Q_{i}^{N}\right)} \\
= & \frac{\operatorname{cov}\left(\alpha+\beta Q^{T}+e_{i}, Q^{N}\right)}{\operatorname{var}\left(Q^{N}\right)} \\
& \operatorname{assume} \operatorname{cov}\left(e, Q^{N}\right)=0 \\
= & \frac{\operatorname{cov}\left(\beta Q^{T}, Q^{N}\right)}{\operatorname{var}\left(Q^{N}\right)} \\
= & \frac{\beta \operatorname{cov}\left(Q^{T}, Q^{N}\right)}{\operatorname{var}\left(Q^{N}\right)} \\
= & \beta \cdot \frac{\operatorname{cov}\left(Q^{N} S^{N}+Q^{O}\left(1-S^{N}\right), Q^{N}\right)}{\operatorname{var}\left(Q^{N}\right)} \\
& \operatorname{substituting} Q^{T}=S_{N} Q^{N}+\left(1-S^{N}\right) Q^{O} \\
= & \beta \cdot \frac{\operatorname{cov}\left(Q^{N} S^{N}, Q^{N}\right)+\operatorname{cov}\left(Q^{O}\left(1-S^{N}\right), Q^{N}\right)}{\operatorname{var}\left(Q^{N}\right)}
\end{aligned}
$$

So the term multiplying $\beta$ in (3) is the expression for the bias that we incur into when trying to estimate the relationship between teacher quality and student outcomes, but observing only the quality of new-regulation teachers.

Cross check: if $S_{i}^{N}=1$ (i.e. if all teachers were new, i.e. if I observed the quality of all teachers, then I would get unbiased estimation:

$$
\begin{aligned}
\hat{\beta} & =\beta \cdot \frac{\operatorname{cov}\left(Q_{i}^{N}, Q_{i}^{N}\right)+0}{\operatorname{var}\left(Q_{i}^{N}\right)} \\
& =\beta \cdot \frac{\operatorname{var}\left(Q_{i}^{N}\right)}{\operatorname{var}\left(Q_{i}^{N}\right)} \\
& =\beta
\end{aligned}
$$

Further notice that in our empirical specification of the relationship of interest we are able to control for a set of variables such as teacher characteristics, subject dummies and subject-specific trends, and school-year fixed effects. That is, all controls used our preferred specification of the main results, Table 3 column (5). In this multivariate regression setting, the formula for the bias changes to:

$$
\frac{\operatorname{cov}\left(\widetilde{Q^{N} S^{N}}, \tilde{Q^{N}}\right)+\operatorname{cov}\left(Q^{O}\left(\widetilde{1-} S^{N}\right), \tilde{Q^{N}}\right)}{\operatorname{var}\left(\tilde{Q^{N}}\right)}
$$


where $\widetilde{v a r}$ indicates the residuals of the regression of var on all available controls.

\section{F.2 Quantification of the bias and estimation of true $\beta$}

Looking at expression (4), we see that the first term at the numerator and the denominator are quantities we are able to compute using our data; see Table A.12 listing the numerical values of each component. The second term at the numerator, $\operatorname{cov}\left(Q^{O}\left(\widetilde{1-} S^{N}\right), \tilde{Q^{N}}\right)$, contains unobserved quantities and we thus proceed establishing lower and upper bounds for its values. By the formula of Pearson's correlation coefficient we have that

$$
-1 \leq \frac{\operatorname{cov}\left(Q^{O} \widetilde{\left(1-S^{N}\right)}, \tilde{Q}^{N}\right)}{\sqrt{\operatorname{var}\left(Q^{O}\left(1-S^{N}\right)\right) \operatorname{var}\left(\tilde{Q}^{N}\right)}} \leq 1
$$

Rearranging terms and imposing the assumption of independence between the residual $\tilde{Q^{N}}$ and

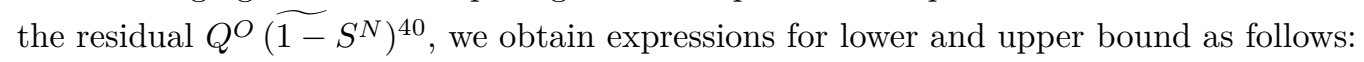

$$
U B, L B= \pm \sqrt{\left[\operatorname{var}\left(\tilde{Q^{O}}\right) \operatorname{var}\left(\tilde{S^{N}}\right)+\operatorname{var}\left(\tilde{Q^{O}}\right) E\left[\tilde{S^{N}}\right]^{2}+\operatorname{var}\left(\tilde{S^{N}}\right) E\left[\tilde{Q}^{O}\right]^{2}\right] \operatorname{var}\left(\tilde{Q^{N}}\right)}
$$

in which the unobserved quantities are $\operatorname{var}\left(\tilde{Q}^{O}\right)$ and $E\left[\tilde{Q}^{O}\right]^{2}$. We show results of the bias estimate for the three cases $\operatorname{var}\left(\tilde{Q^{O}}\right) \approx \operatorname{var}\left(\tilde{Q^{N}}\right), \operatorname{var}\left(\tilde{Q^{O}}\right) \simeq 2 \operatorname{var}\left(\tilde{Q^{N}}\right)$ and $\operatorname{var}\left(\tilde{Q^{O}}\right) \simeq \frac{1}{2} \operatorname{var}\left(\tilde{Q^{N}}\right)$, which respectively represent the scenario in which the residual variance of old-regulation teacher quality (after accounting for the available controls) is approximately as large as, double as much, and half as much as the residual variance of new-regulation teacher quality. Regarding the term $E\left[\tilde{Q^{O}}\right]^{2}$, it will be sufficient to assume its value not to differ by several oders of magnitude from $E\left[\tilde{Q^{N}}\right]$.

\section{G Survival Analysis Extensions}

\section{G.1 All teachers}

In this section we show the results of our survival analysis extending the sample to all 360,644 teachers recorded teaching in any public preschool, primary or secondary school in the country, among which 214,920 belong to the Old regulation and 145,724 to the New one. As in the previous analysis on secondary school teachers, we have excluded teachers who voluntarily switched from the Old to

\footnotetext{
${ }^{40}$ which greatly simplifies the decomposition of the term $\operatorname{var}\left(Q^{O}\left(1-S^{N}\right)\right)$
} 
Table A.12: Empirical values of bias components

Component Value in sample*

\begin{tabular}{|c|c|c|}
\hline 1. & $\operatorname{cov}\left(\widetilde{Q^{N} S^{N}}, \tilde{Q^{N}}\right)$ & $\approx 26.22$ \\
\hline \hline 2. & $\operatorname{var}\left(\tilde{Q^{N}}\right)$ & $\approx 43.31$ \\
\hline \hline 3. & $\operatorname{var}\left(\tilde{S^{N}}\right)$ & $\approx 0.04$ \\
\hline \hline 4. & $E\left[\tilde{S^{N}}\right]$ & $\approx 2.61 e^{-12}$ \\
\hline \hline 5. & $E\left[\tilde{Q^{N}}\right]$ & $\approx-7.43 e^{-10}$ \\
\hline
\end{tabular}

* Sample used for main results (Table 3).

the New Regulation (by taking the exam) and the other cases in which the regulation recorded is inconsistent with the year of hiring, as well as the teachers who are recorded as not exercising in an educational structure.

\section{G.2 Survival functions by entry score deciles}

Given the interesting results described in Section 8.1 about survival patterns by entry exam scores, we expand the analysis by looking at score deciles instead of quartiles, in order to detect potentially finer patterns. The analysis on deciles reflects the conclusions of the one on quartiles: teachers in the lowest three score deciles show the worst survival patterns, but at higher score levels the relationship between scores and expected survival is not monotonic, with survival improving at first, peaking at the mid of the distribution (5th decile) and then lowering somewhat, with the highest scores showing on average lower survival rates than mid-range scorers. 
Figure A.2: Kaplan-Meier survivor functions by regulation - All teachers

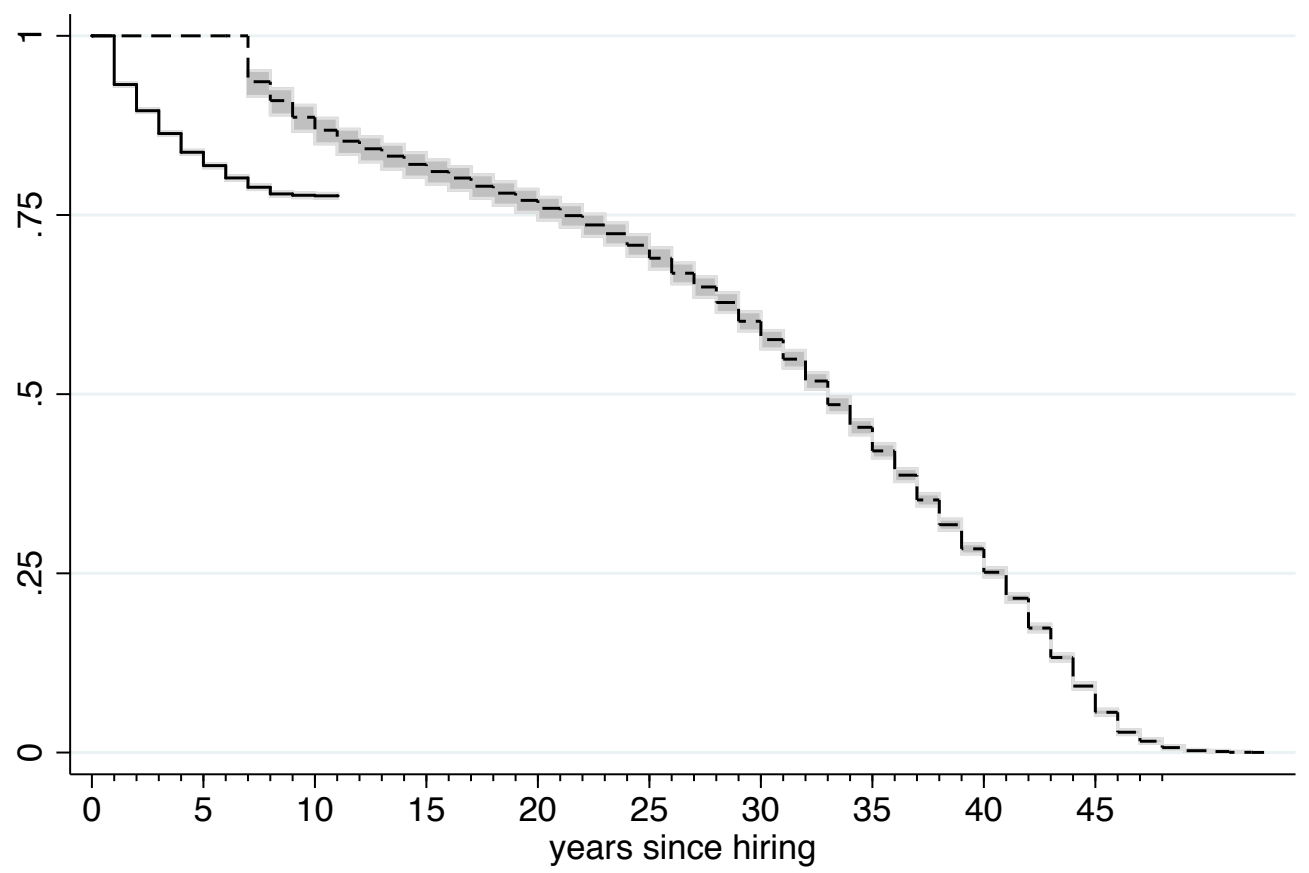

Kaplan-Meier survivor functions for teachers belonging to the new regulation (solid line) and the old regulation (dashed line), and $95 \%$ confidence intervals. 
Figure A.3: Kaplan Meier survival functions by teacher characteristics (Old regulation) - All teachers
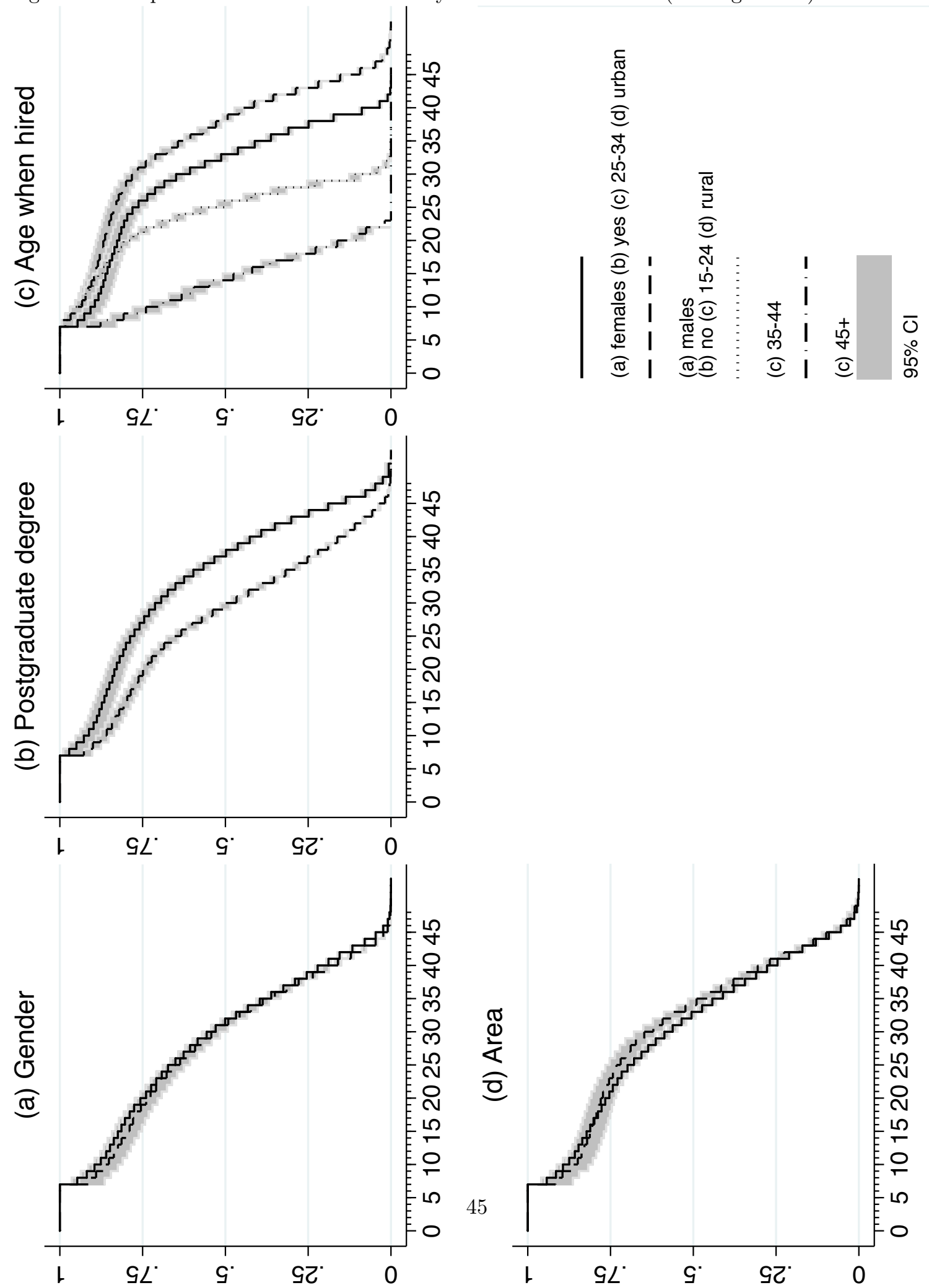
Figure A.4: Kaplan Meier survival functions by teacher characteristics (New regulation) - All teachers
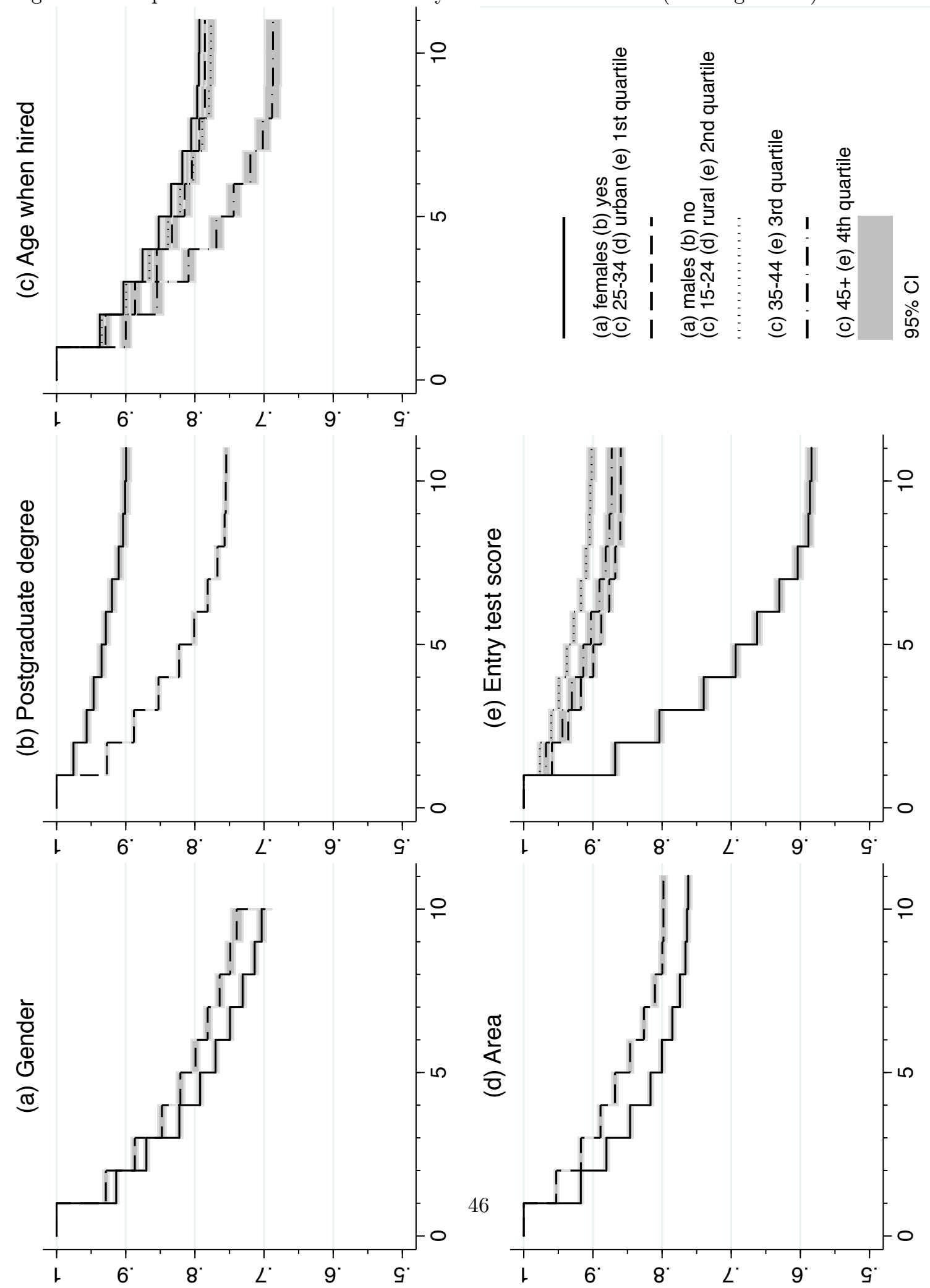
Figure A.5: Kaplan Meier survival functions by entry test score deciles

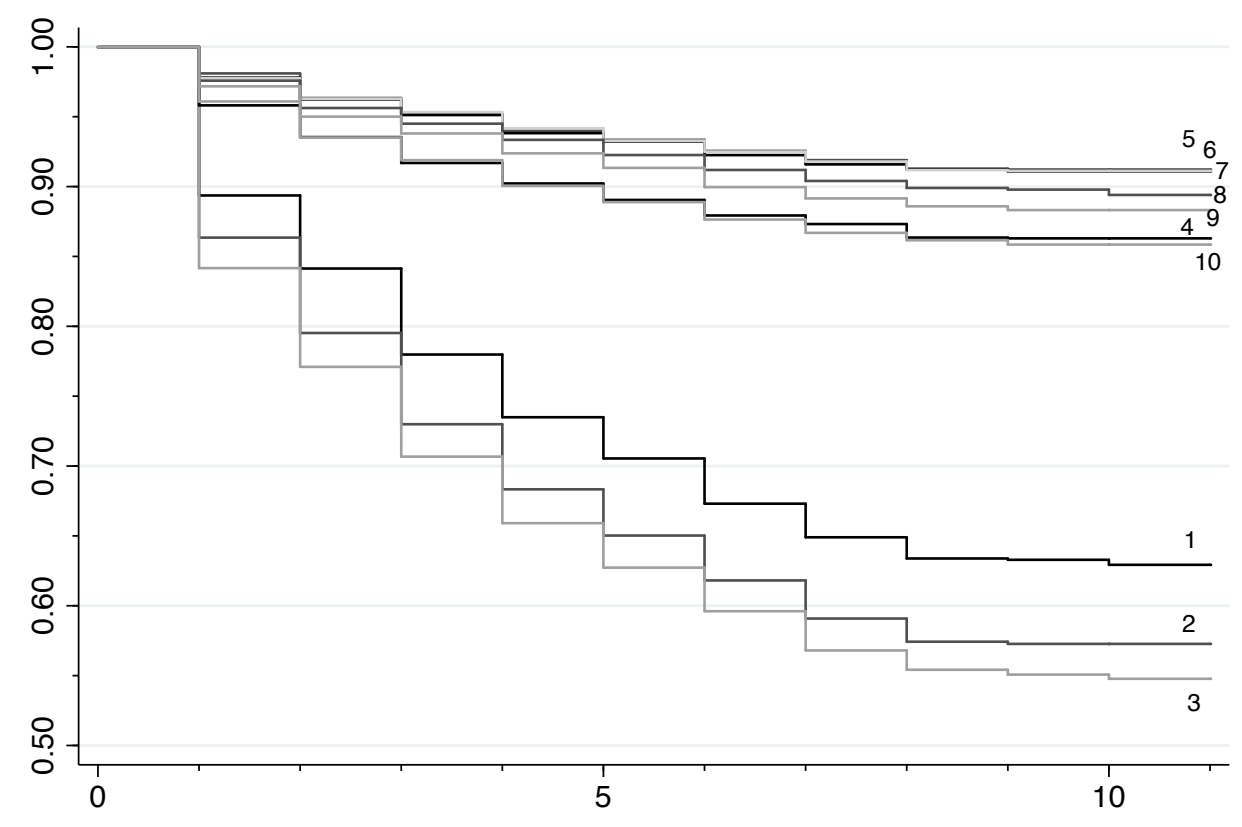

(a) All teachers

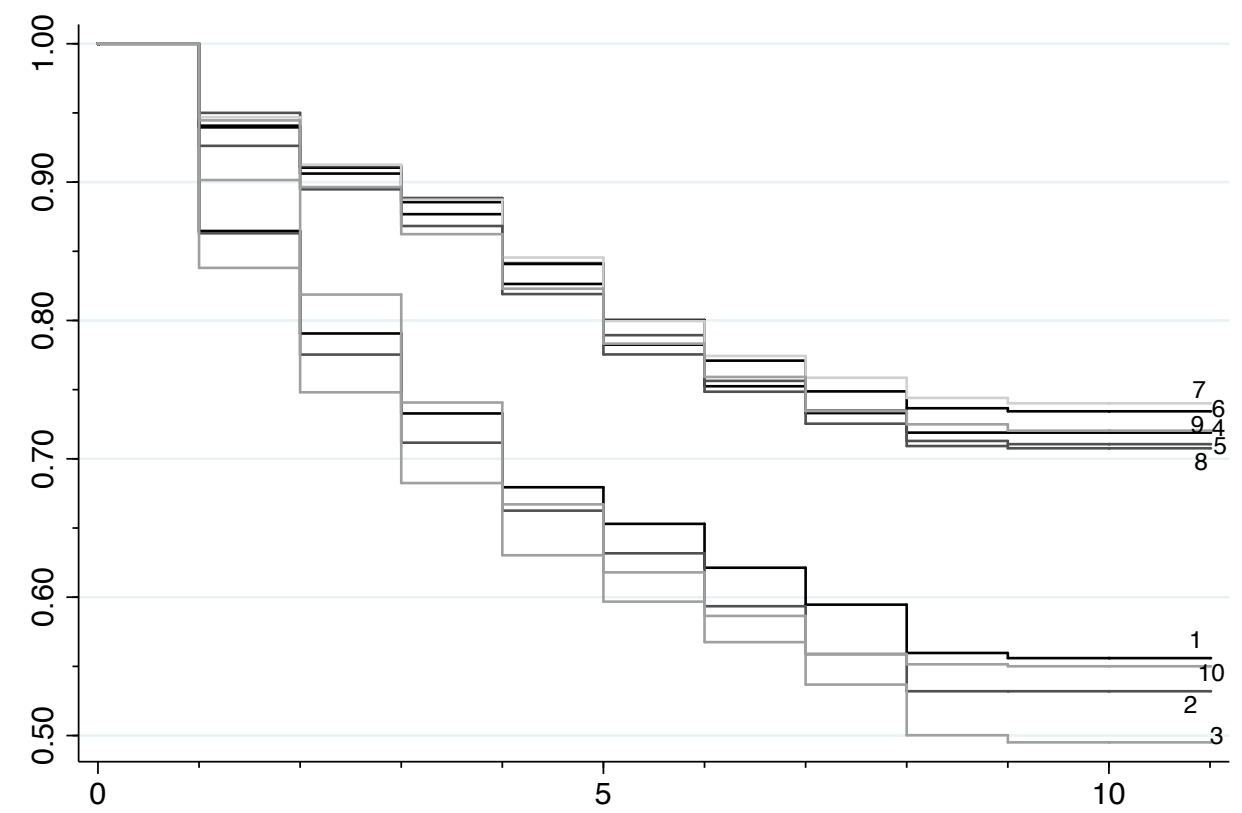

(b) Saber 11 teachers 